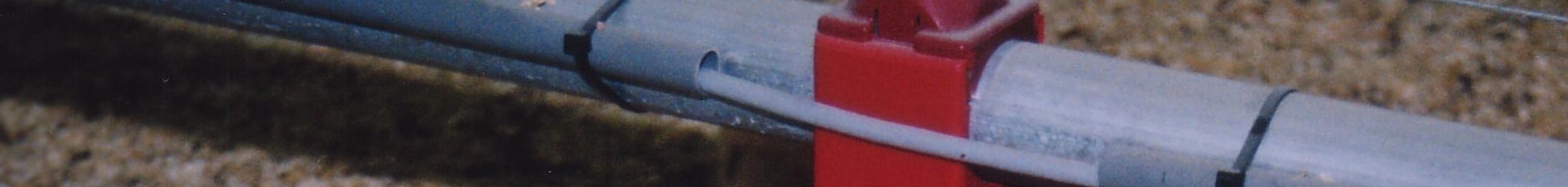

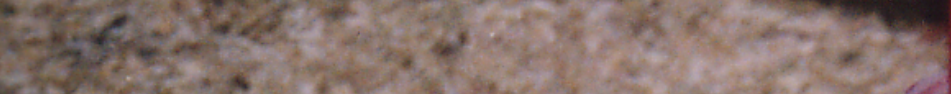

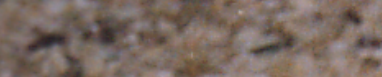

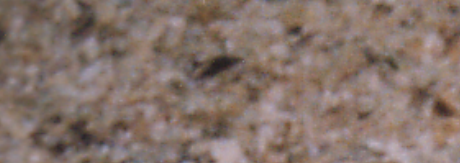

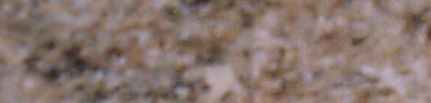

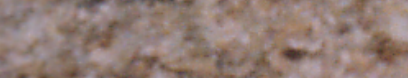

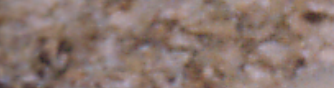

c.
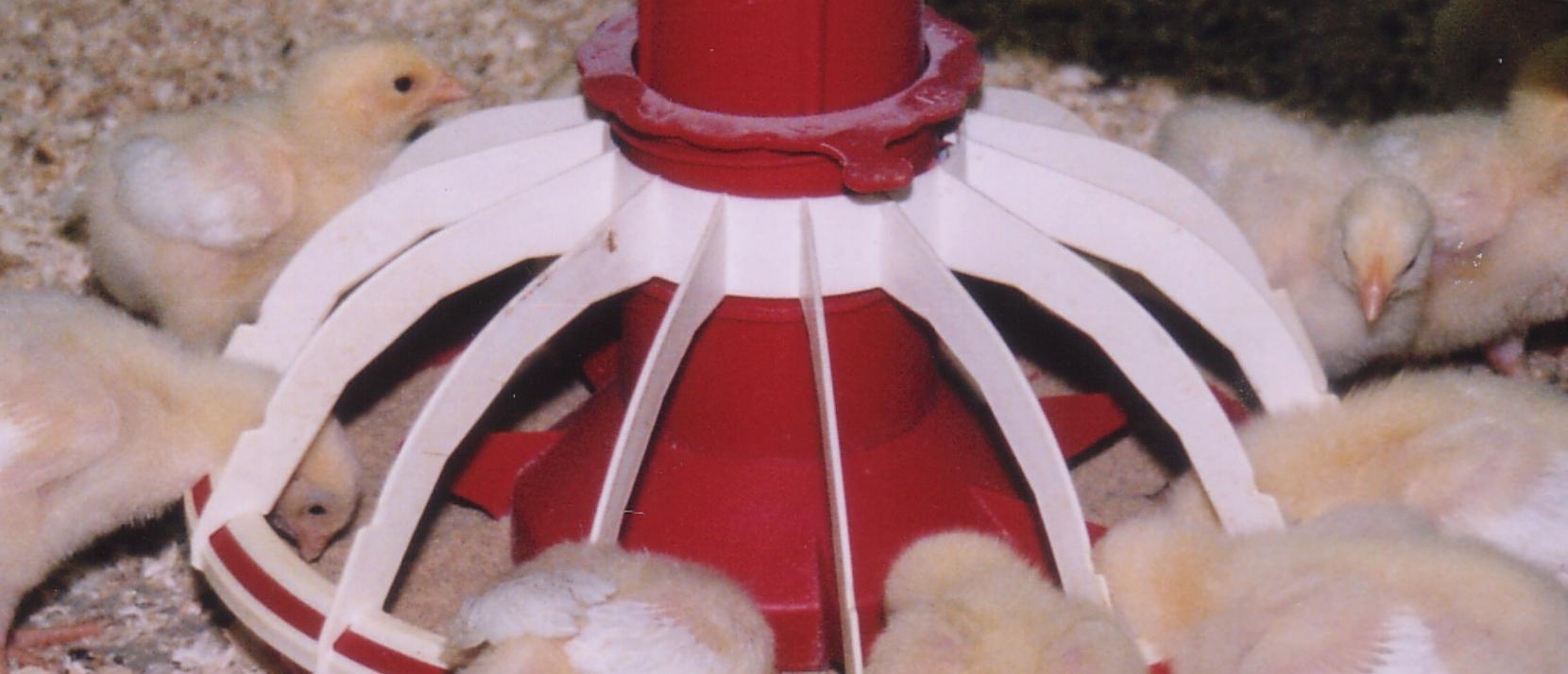

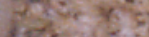

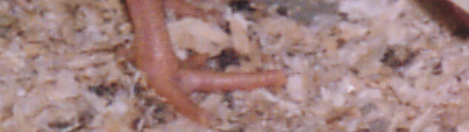

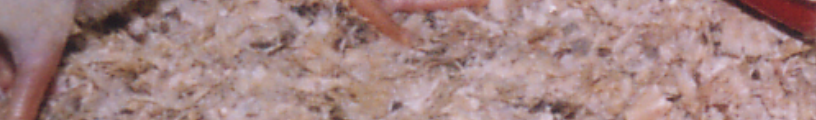

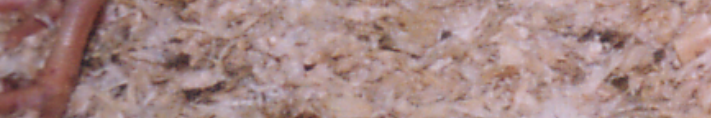

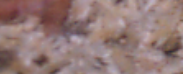
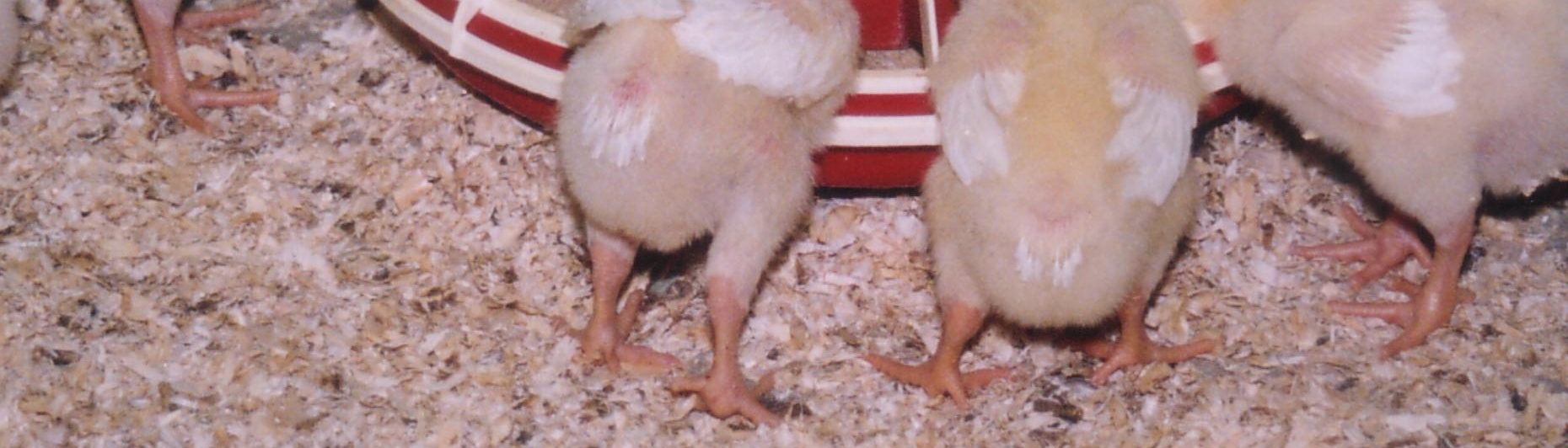

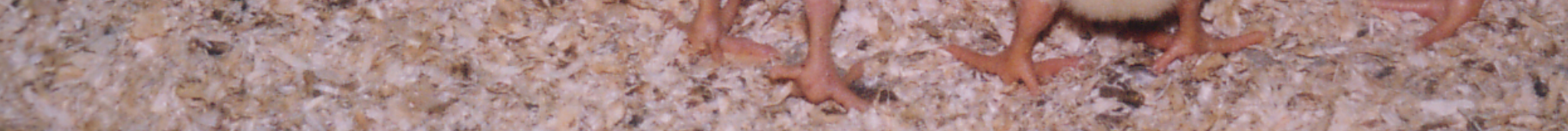

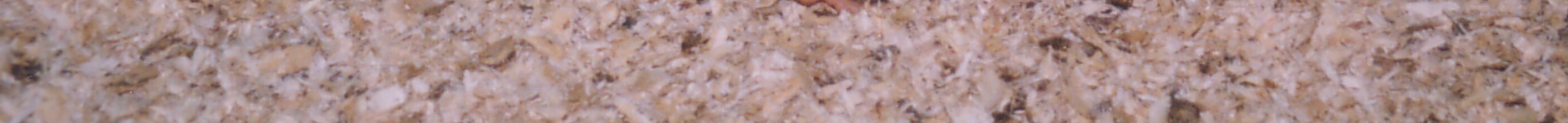

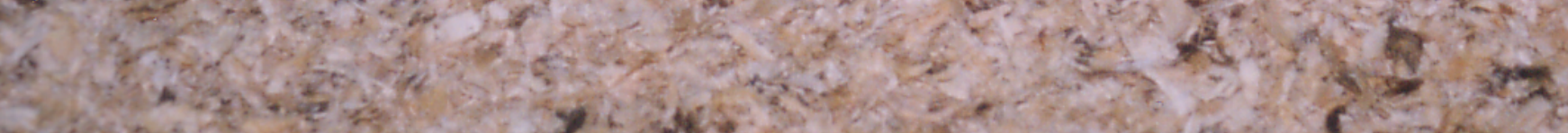

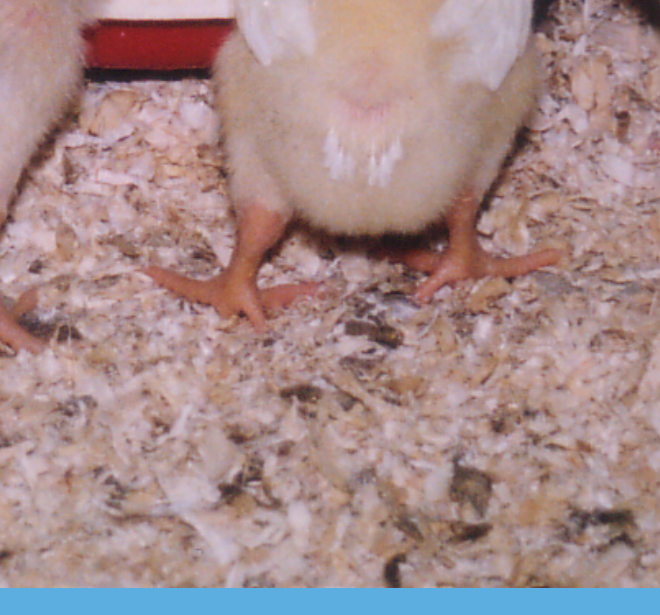

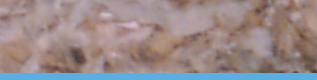

Effect of iso-energetic exchange of dietary fat and starch on growth performance and body composition of broilers; Experiment 2

T. Veldkamp, R. Dekker, A. Smit-Heinsbroek, A. van der Lee, A.J.M. Jansman 



\section{Effect of iso-energetic exchange of dietary fat and starch on growth performance and body composition of broilers}

\section{Experiment 2}

T. Veldkamp ${ }^{1}$, R. Dekker ${ }^{1}$, A. Smit-Heinsbroek², A. van der Lee², A.J.M. Jansman ${ }^{1}$

${ }^{1}$ Wageningen UR Livestock Research, Wageningen, The Netherlands

${ }^{2}$ Agrifirm Innovation Center, Apeldoorn, The Netherlands

This research was conducted by Wageningen UR Livestock Research, within the framework of the public private partnership "Feed4Foodure" and partially funded by the Ministry of Economic Affairs (Policy Support Research; project number BO-31.03-005-001)

Wageningen UR Livestock Research

Wageningen, November 2017

Report 1062 
Veldkamp, T., R. Dekker, A. Smit-Heinsbroek, A. van der Lee, A.J.M. Jansman, 2017. Effect of isoenergetic exchange of dietary fat and starch on growth performance and body composition of broilers - Experiment 2. Wageningen, Wageningen Livestock Research, Livestock Research Report 1062.

\section{Samenvatting}

De concentraties eiwit/aminozuren, vet en koolhydraten en hun ratio's kunnen het post-absorptieve energie-metabolisme en de aanzet van energie en eiwit in het lichaam beïnvloeden. In een $2 \times 3$ factorieel experiment zijn de effecten van twee ruw eiwit (hoog eiwit (HP) vs. laag eiwit (LP) concentraties; $200 / 190$ vs. $170 / 160 \mathrm{~g} / \mathrm{kg}$ ) in de groei- en eindfase en drie vet/zetmeel concentraties ( hoog vet (HF); vet en zetmeel respectievelijk 120 en $350 \mathrm{~g} / \mathrm{kg}$, medium vet (MF); vet en zetmeel respectievelijk 80 en $425 \mathrm{~g} / \mathrm{kg}$ en laag vet (LF); vet en zetmeel respectievelijk 40 en $500 \mathrm{~g} / \mathrm{kg}$ ) op productieparameters en lichaamssamenstelling van Ross 308 vleeskuikens onderzocht in de periode van 8 tot 38 dagen leeftijd. Geconcludeerd kan worden dat de energiebron en het eiwitgehalte in isoenergetische voeders, gebalanceerd voor de eerst limiterende essentiële aminozuren, invloed hebben op groeiparameters en lichaamssamenstelling van vleeskuikens.

\section{Summary}

Dietary factors such as the concentrations of protein/amino acids, fat, and starch + sugar and their ratio, may affect the post-absorptive metabolism of energy and protein and energy deposition in the body. In a $2 \times 3$ factorial block design, the effects of two dietary crude protein (high protein (HP) vs. low protein (LP) concentrations; $200 / 190$ vs. $170 / 160 \mathrm{~g} / \mathrm{kg}$ ) in grower and finisher phase and three dietary fat/starch concentrations (high fat (HF); fat and starch 120 and $350 \mathrm{~g} / \mathrm{kg}$, respectively, medium fat (MF); fat and starch 80 and $425 \mathrm{~g} / \mathrm{kg}$ and low fat (LF); fat and starch 40 and $500 \mathrm{~g} / \mathrm{kg}$, respectively) on growth performance and body composition of Ross 308 broilers were studied ( 8 to 38 d). From this experiment it can be concluded that dietary energy source and protein level in isoenergetic diets, balanced for first limiting essential amino acids, influence growth performance and body composition of broilers.

This report can be downloaded for free at https://doi.org/10.18174/429935 or at www.wur.nl/ livestock-research (under Wageningen Livestock Research publications).

(c) 2017 Wageningen Livestock Research, P.O. Box 338, 6700 AH Wageningen, The Netherlands, T +31 (0)317 4839 53, E info.livestockresearch@wur.nl, www.wageningenUR.nl/en/livestockresearch.

All rights reserved. No part of this publication may be reproduced and/or made public, whether by print, photocopy, microfilm or any other means, without the prior permission of the publisher or author.

The ISO 9001 certification by DNV underscores our quality level. All our research commissions are in line with the Terms and Conditions of the Animal Sciences Group. These are filed with the District Court of Zwolle.

Livestock Research Report 1062 


\section{Table of contents}

$\begin{array}{ll}\text { Foreword } & 5\end{array}$

$\begin{array}{ll}\text { Summary } & 7\end{array}$

1

Introduction $\quad 9$

$\begin{array}{lll}1.1 & \text { Objectives } & 10\end{array}$

2

$\begin{array}{ll}\text { Material and Methods } & 11\end{array}$

$2.1 \quad$ Experimental animals 11

$\begin{array}{lll}2.2 & \text { Experimental treatments and design } & 11\end{array}$

$\begin{array}{lll}2.3 & \text { Experimental diets and feeding } & 11\end{array}$

$\begin{array}{lll}2.4 & \text { Housing and management } & 15\end{array}$

$\begin{array}{lll}2.5 & \text { Observations during the study } & 15\end{array}$

$\begin{array}{lll}2.6 & \text { Statistics } & 16\end{array}$

3

$\begin{array}{ll}\text { Results and Discussion } & 17\end{array}$

$\begin{array}{lll}3.1 & \text { Growth performance } & 17\end{array}$

3.2 Carcass yields 18

$\begin{array}{lll}3.3 & \text { Body composition } & 19\end{array}$

3.4 Nutrient digestion $\quad 24$

$\begin{array}{lll}3.5 & \text { Litter quality and foot pad quality } & 25\end{array}$

$\begin{array}{lll}3.6 & \text { Sieve analyses experimental diets } & 25\end{array}$

$\begin{array}{llr}4 & \text { Conclusions } & 27\end{array}$

$5 \quad$ References $r$

Appendix 1 Feed and nutrient composition of the starter diet 31

Appendix 2 Growth performance of broilers from 8 to 28 days of age 32

Appendix 3 Growth performance of broilers from 29 to 38 days of age 33 


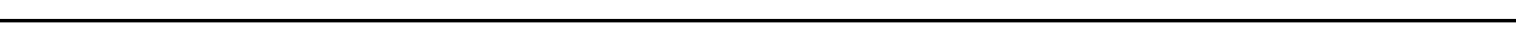




\section{Foreword}

Feed4Foodure is a public-private partnership between the Dutch Ministry of Economic Affairs, a consortium of various organizations within the animal production chain and Wageningen Livestock Research. Feed4Foodure aims to contribute to sustainable and healthy livestock farming in the Netherlands, simultaneously strengthening its competitive position on the global market. The Feed4Foodure program line "More-with-Less by efficient nutrient use", aims to reduce the footprint of the Dutch livestock sector in the field of phosphate, nitrate, copper, zinc, ammonia and greenhouse gases. New nutritional models and measurement techniques will help to improve efficient use of nutrients in livestock farming.

The current report describes the second experiment in a series of three experiments that were conducted to investigate the effect of iso-energetic exchange of dietary fat and starch on growth performance and body composition of broilers. For the current study, scientists of Wageningen Livestock Research worked together with representatives from the consortium and thank the industry partners of the project team for their worthwhile input.

Dr. Teun Veldkamp, project leader

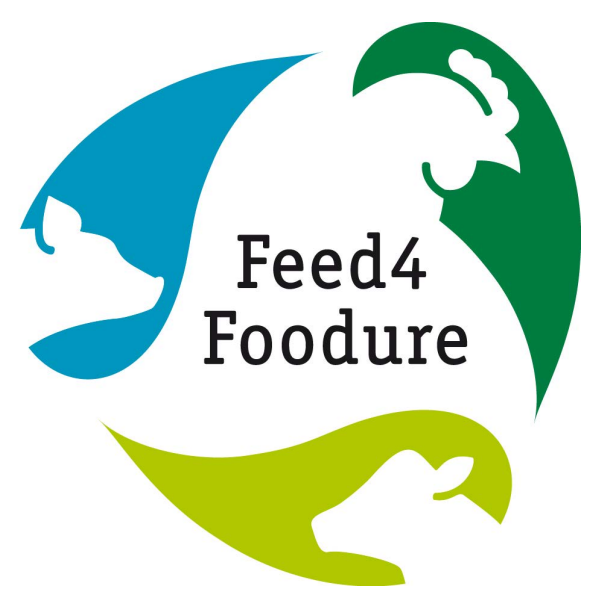




\section{Summary}

Macro-nutrients such as the concentrations of protein/amino acids, fat, and starch + sugars and their ratio, may affect the post-absorptive metabolism of energy and protein and energy deposition in broilers. In a 2x3 factorial block design, the effects of two dietary crude protein (high protein (HP) vs. low protein (LP) concentrations; $200 / 190 \mathrm{vs.} 170 / 160 \mathrm{~g} / \mathrm{kg}$ ) in grower and finisher phase and three dietary fat/starch concentrations (high fat (HF); fat and starch 120 and $350 \mathrm{~g} / \mathrm{kg}$, respectively, medium fat (MF); fat and starch 80 and $425 \mathrm{~g} / \mathrm{kg}$, respectively and low fat (LF); fat and starch 40 and $500 \mathrm{~g} / \mathrm{kg}$, respectively) on growth performance and body composition of Ross 308 broilers were studied ( 8 to 38 days of age). Concentrations of apparent faecal digestible essential amino acids were similar in HP and LP diets but higher than in experiment 1; (CVB, 2012) + 10\%. Overall, body weight gain of broilers fed HP diets was significantly higher than body weight gain of broilers fed LP diets ( 59.6 vs. $58.3 \mathrm{~g} ; \mathrm{P}<0.001$ ) and feed conversion ratio of birds fed HP diets was significantly lower than feed conversion ratio of broilers fed LP diets ( 1.65 vs. 1.68; $P=0.037$ ). Despite a higher inclusion level of free essential amino acids in LP diets, faecal digestible amino acids $10 \%$ higher than recommended by CVB (2012), growth performance of birds fed LP diets was lower than on HP diets. The concentration of non-essential amino acids in LP diets related to the $30 \mathrm{~g} / \mathrm{kg}$ lower crude protein concentration may still have been limiting body weight gain in LP diets compared to HP diets. Body weight gain of broilers increased as starch concentration in the diet was increased (HF: $55.3 \mathrm{~g} / \mathrm{d}$, MF: $59.5 \mathrm{~g} / \mathrm{d}$ and LF: $62.1 \mathrm{~g} / \mathrm{d}$; $\mathrm{P}<0.001$ ). Feed conversion ratio of broilers decreased significantly as starch concentration in the diet increased (HF: 1.74, MF: $1.69, \mathrm{LF}: 1.57 ; \mathrm{P}<0.001$ ). The exchange of dietary fat by starch in MF and LF diets resulted in a significantly higher body weight gain and significantly lower FCR. Overall, body composition of broilers fed HP diets showed a lower DM content, a higher protein content and a lower fat content compared to broilers fed LP diets. Body DM and fat content in broilers fed HF diets was lower than in broilers fed LF diets up to 28 days of age. Body ash and protein content were not affected by dietary energy source. Protein deposition in broilers fed LF diets was higher than in broilers fed HF diets. Fat deposition in broilers fed LF diets was higher than in the body of broilers fed HF diets until 28 days of age. Digestibility of CP in broilers fed LF diets was higher than in broilers fed HF diets whereas digestibility of fat was not affected by dietary fat/starch concentration. The higher CP digestibility in broilers fed LF diets may have contributed to the higher growth performance and higher CP deposition in birds fed LF diets. The difference in fat deposition in broilers fed LF and HF diets can be related to the higher CP digestibility in birds fed LF diets, however fat digestibility was not affected by dietary fat/starch concentration. Obtained differences in nutrient deposition can be due to differences in post-absorptive metabolism and retention. 


\section{Introduction}

The subproject Feed4Foodure MMM2A quantifies the effect of nutritional interventions on the energy losses in pigs and poultry (broilers as well as layers) husbandry, and on the methane losses in ruminant nutrition. The current report describes the second in a series of three experiments that were conducted to investigate the effect of iso-energetic exchange of dietary fat and starch on the growth performance and body composition of broilers. Energy losses appear as a result of an indigestible part of dietary energy and excretion in the excreta, the synthesis and losses of endogenous protein that is excreted in the digestive tract and excreted in the excreta, energy use for different maintenance processes and subsequently reveal as heat losses and post-absorptive energy metabolism (inefficient use of energy for protein and fat deposition in the body). Poultry breeders are selecting broilers for higher body weight gain and breast muscle. The mean daily body weight gain has increased by $5 \mathrm{~g}$ and the breast meat yield has increased by $0.5 \%$ in the last decade. This selection of animals may affect the protein and fat metabolism considerably. Energy deposition is the resultant of dietary energy intake and the efficiency of utilization of energy for maintenance and for deposition of protein and fat in the body. Besides genetic factors also exogenic factors, such as climate and nutrition (feed intake and diet composition, affect the energy partitioning in the body. Literature is available on the effect of ratio of dietary macro-nutrients (protein, fat and starch + sugar) on growth performance and body composition of broilers ((Jackson et al., 1982; Laurin et al., 1985; MacLeod, 1990, 1992; Nieto et al., 1997 Collin et al., 2003; Swennen et al., 2005, 2007). In general, diets containing high concentrations of metabolisable energy or a high energy-protein ratio result in a higher fat deposition (Swennen et al., 2007). Dietary protein concentration above the protein/amino acid requirement will result in broilers with a lower body fat content and with a lower efficiency because degradation and excretion of the surplus amino acids are energy demanding processes. A reduction of the dietary protein concentration to suboptimal levels, whereby the supply of essential amino acids and/or the total of provided nitrogen are below requirement, will result in a higher fat deposition (Buyse et al., 1992). Many studies in literature were focusing on the effect of dietary protein concentration and less attention was paid on the effect of dietary fat and carbohydrate concentrations on growth performance and deposition of protein and fat in the body. Eits (2004) concluded that protein deposition increased as dietary protein concentration was increased. In case the dietary protein intake was restricted, the protein deposition in the body could not be increased by the supply of extra dietary energy. Body weight gain was significantly lower and fat deposition was significantly higher in broilers fed isoenergetic diets (low in fat or low in carbohydrate concentration) with low crude protein (12.6\%) than in broilers fed diets with standard crude protein concentration (19.7\%). Effects of starch + sugar in the diet on insulin levels in the blood and stimulation of protein synthesis and limitation of protein degradation have been described in literature on humans and pigs. Starch + sugar may have a protein-sparing effect in monogastrics (Fuller et al., 1977) and a higher inclusion level of starch + sugar in the diet may increase the nitrogen retention. Different studies suggest that the hormones glucagon and insulin play an import role; insulin decreases protein degradation and stimulates protein synthesis (Bennet et al., 1990; Biolo et al., 1995), while glucagon stimulates amino acid catabolism (Mallette et al., 1969; Flakoll et al., 1994). Rabinowitz et al. (1966) showed that when proteins were ingested alone, there was a large increase in plasma glucagon and a small elevated plasma insulin level. But, when proteins and carbohydrates were ingested together, insulin release was enhanced (Nuttal et al., 1984). In literature related to human and pigs it is clear that there is an effect of dietary starch + sugars intake on insulin levels, which resulted in the stimulation of protein synthesis and restriction of protein degradation (Calbet et al., 2002; Camp et al., 2003). Camp et al. (2003) found a positive effect of higher inclusion levels of sucrose on body weight gain and feed efficiency in growing pigs. In rats, Fulks et al. (1975) found that glucose by itself inhibited protein degradation but in the absence of insulin, glucose had no significant effect on protein. Furthermore, Houston and O' Neill (1991) showed that insulin stimulated the secretion of IGF-I by chicken hepatocytes and acts synergistically with growth hormone $(\mathrm{GH})$ to increase IGF-I release. The GH secretion in poultry stimulates production and secretion of IGF 1 from the liver, which is the major source of circulating 
IGF 1 (Buyse et al., 2000). IGF 1 and FFA's exert a negative feedback to the hypothalamic- pituitary axis to suppress GH secretion (Buyse et al., 2000). GH has important and direct effects on the liver and adipose tissue, whereas effects on skeletal muscle are mostly mediated by IGF 1 (Scanes, 2009). Malheiros et al. (2003) showed that chickens on a low protein diet had decreased plasma IGF-I level. Increased plasma FFA levels were measured in broilers on a low fat (high carbohydrate) diet compared to broilers on a high fat (low carbohydrate) diet (Malheiros et al,. 2003). These findings contradicts with those of Tanaka et al. (1983), who showed that adding fat to a diet resulted in increased FFA levels. However, the diets used by Malheiros et al. (2003) were iso-energetically formulated. Malheiros et al. (2003) showed that a low protein diet increased fat deposition in broilers compared to chickens with a normal protein diet. The broilers fed a low protein diet had higher plasma triglyceride (TG) levels, which is also reported in other studies (Tanaka et al., 1983; Rosebrough et al., 1996; Collin et al., 2003; Swennen et al., 2005, 2007). Triglycerides are the main product of the de novo hepatic lipogenesis in the chicken.

From the literature it is concluded that a higher concentration of dietary starch + sugar may have a positive effect on growth performance and processing yields as higher concentrations of dietary starch + sugar will affect glucose and insulin levels in the blood. However, in poultry, no consistent effects were reported when dietary fat as energy source was exchanged by starch + sugar. The results of a first experiment to study the effect of iso-energetic exchange of dietary fat and starch on growth performance and body composition of broilers are reported in Livestock Research Report 1061 and in the current report referred to as Experiment 1. Contrasts in dietary fat/starch concentrations between different dietary treatments in the second large scale experiment were larger than in the first experiment. In the first experiment the high fat diets (HF) contained $105 \mathrm{~g} / \mathrm{kg}$ fat and $380 \mathrm{~g} / \mathrm{kg} \mathrm{starch}$ and the low fat diets (LF) contained $65 \mathrm{~g} / \mathrm{kg}$ fat and $460 \mathrm{~g} / \mathrm{kg}$ starch. In the second experiment three different fat/starch concentrations were studied: high fat (HF; fat and starch 120 and $350 \mathrm{~g} / \mathrm{kg}$, respectively), medium fat (MF; fat and starch 80 and $425 \mathrm{~g} / \mathrm{kg}$, respectively) and low fat (LF; fat and starch 40 and $500 \mathrm{~g} / \mathrm{kg}$, respectively).

The difference in crude protein concentration between high protein (HP) and low protein (LP) diets of $30 \mathrm{~g} / \mathrm{kg}$ was studied in experiment 1 as well as in experiment 2. Free amino acids lysine, methionine, threonine, valine, arginine, isoleucine and tryptophan were supplemented to fulfil the CVB (2012) requirement for faecal digestible amino acid concentrations. In experiment 1 growth performance of broilers fed LP diets was lower than growth performance of broilers fed HP diets. Therefore, in experiment 2 higher concentrations of free amino acids were supplemented in order to create apparent faecal digestible amino acid concentrations 10\% higher than CVB (2012) recommendations to avoid deficiencies in essential amino acids.

Furthermore, it was not clear why the effect of exchange of fat by starch had a more pronounced effect in LP diets than in HP diets. In rats, Fulks et al. (1975) found in a study with rats that glucose by itself inhibited protein degradation. This hypothesis was confirmed in the first experiment but mainly in LP diets. Possibly the protein sparing effect of glucose can mainly be observed in diets where protein concentration is limiting. Protein retention was probably maximal in HP and could not be improved further. Experimental diets for experiment 2 were formulated iso-energetic again by use of similar feed ingredients as in experiment 1 . In experiment 1 , response of broilers to dietary treatments was not affected by gender and therefore only males have been used in experiment 2 . The second experiment was conducted as a follow-up of the first experiment to further evaluate the results of the first experiment with larger contrasts between fat/starch concentrations.

\subsection{Objectives}

The objective of the experiment was to study the effect of iso-energetic exchange of dietary fat and starch on growth performance and body composition of broilers. 


\section{$2 \quad$ Material and Methods}

\section{$2.1 \quad$ Experimental animals}

The experiment was conducted with 6480 male broilers (Ross 308) divided among 36 pens. The number of broilers per pen was 180. Broilers were obtained from the commercial hatchery Probroed \& Sloot, Meppel, The Netherlands. Day-old broilers were counted and housed ad random. Day-old broilers were vaccinated against IB in the hatchery, NCD (spray vaccination) at 14 days of age and Gumboro at 17 days of age at the experimental facility.

\subsection{Experimental treatments and design}

A two level factorial experiment was conducted in which two factors were investigated. Dietary crude protein concentration at two levels and dietary fat/starch concentrations at three levels. The six experimental diets were randomly assigned to blocks six pens situated next to each other ( 6 pens per diet) from 8 days of age.

The two dietary crude protein concentrations were: high dietary protein (HP) vs. low dietary protein (LP) concentrations; $200 / 190$ vs. $170 / 160 \mathrm{~g} / \mathrm{kg}$ in the grower and finisher phase, respectively. The three dietary fat/starch concentrations were: high dietary fat (HF) concentrations (dietary fat and starch 120 and $350 \mathrm{~g} / \mathrm{kg}$, respectively), medium dietary fat (MF) concentrations (dietary fat and starch 80 and $425 \mathrm{~g} / \mathrm{kg}$, respectively) and low dietary fat (LF) concentrations (dietary fat and starch 40 and $500 \mathrm{~g} / \mathrm{kg}$, respectively). The experimental factors are summarized in Table 1.

Table 1 Overview of the experimental factors

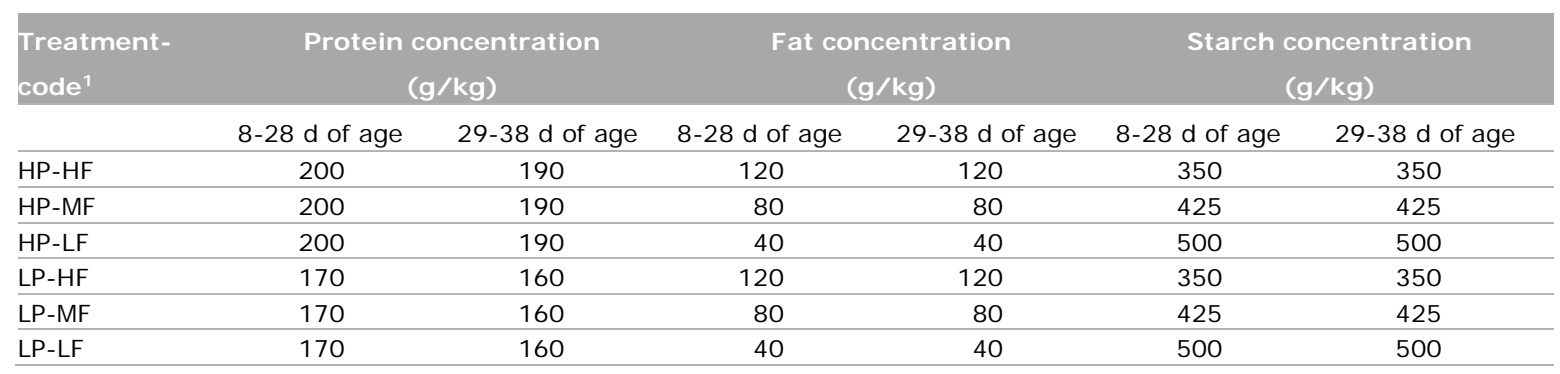

${ }^{1}$ HP (high protein), LP (low protein), HF (high fat), MF (medium fat), LF (low fat)

\subsection{Experimental diets and feeding}

A commercial starter diet was provided to the broilers during the starter phase from 0 to $8 \mathrm{~d}$ of age. The feed composition of the starter diet is presented in Appendix 1 . All diets were fed as crumbles to avoid effects of pellet quality on response of broilers. The grower and finisher diet were fed in the periods from 8 to $28 \mathrm{~d}$ of age and 29 to $38 \mathrm{~d}$ of age, respectively. The two dietary crude protein concentrations in the experimental diets in the grower and finisher phase were: high dietary protein (HP) vs. low dietary protein (LP) concentrations; 200/190 vs. 170/160 g/kg in the grower and finisher phase, respectively). The three dietary fat/starch concentrations were: high dietary fat (HF) concentrations (dietary fat and starch 120 and $350 \mathrm{~g} / \mathrm{kg}$, respectively), medium dietary fat (MF) concentrations (dietary fat and starch 80 and $425 \mathrm{~g} / \mathrm{kg}$, respectively) and low dietary fat (LF) concentrations (dietary fat and starch 40 and $500 \mathrm{~g} / \mathrm{kg}$, respectively). Essential amino acids lysine, methionine, threonine, valine, arginine, isoleucine and tryptophan were supplemented to create apparent faecal digestible amino acid requirements 10\% higher than (CVB, 2012) recommendations. The restricted number of protein-rich feed ingredients (soybean meal, potato protein and corn gluten meal) was decreased proportionally to create the diets with low dietary protein concentrations in order 
to avoid large differences in inclusion levels of feed ingredients between high (HP) and low (LP) protein diets. In the feed formulation it was pursued to create a difference of $30 \mathrm{~g} / \mathrm{kg}$ in crude protein concentration between HP and LP diets. In the feed formulation it was pursued further to create a difference of $80 \mathrm{~g} / \mathrm{kg}$ in crude fat concentration and a difference of $150 \mathrm{~g} / \mathrm{kg}$ in starch concentration between high fat (HF) and low fat (LF) diets. All grower and finisher experimental diets were formulated to be iso-energetic ( $2975 \mathrm{kcal} \mathrm{ME} / \mathrm{kg}$ ). Feed ingredients with a high crude fibre and/or fat concentration were exchanged by starch or feed ingredients rich in starch in order to realize isoenergetic diets. Experimental diets were also formulated to have an identical electrolyte balance $(\mathrm{Na}+\mathrm{K}-\mathrm{Cl})$. Diamol was used as an inert filler. In the finisher diet an inert marker $\left(\mathrm{TiO}_{2}\right)$ was included to determine faecal digestibility of nutrients in the finisher diet. Feed and nutrient composition of the grower and finisher experimental diets are presented in Table $2 a$ and 2b, respectively. In these Tables the feed ingredients and nutrient composition of HP-HF, HP-LF, LP-HF and LP-LF are presented as these diets were produced in the feed mill of ABZ Leusden. The two dietary treatments HP-MF and LPMF were created by use of an accurate weighing and mixing unit in the experimental broiler house. 
Table 2a Ingredient and nutrient composition of experimental grower diets in $\mathrm{g} / \mathrm{kg}$ unless stated otherwise (8-28 $d$ of age)

\begin{tabular}{|c|c|c|c|c|c|c|c|c|c|}
\hline & $\begin{array}{l}\text { Unit/ } \\
\text { kg }\end{array}$ & HP-HF ${ }^{1}$ & & HP-LF ${ }^{1}$ & & LP-HF ${ }^{1}$ & & LP-LF ${ }^{1}$ & \\
\hline \multicolumn{10}{|l|}{ Feed ingredient } \\
\hline Corn & \multicolumn{3}{|c|}{204.7} & \multicolumn{2}{|c|}{365.4} & \multicolumn{2}{|c|}{247.3} & \multicolumn{2}{|l|}{408.6} \\
\hline Wheat & \multicolumn{3}{|c|}{224.9} & \multicolumn{2}{|c|}{225.0} & \multicolumn{2}{|l|}{225.0} & \multicolumn{2}{|l|}{225.0} \\
\hline Soybean meal & \multicolumn{3}{|c|}{164.2} & \multicolumn{2}{|c|}{129.0} & 162.4 & & 126.9 & \\
\hline Potato protein (Promyl FF) & & 35.0 & & 35.1 & & 19.9 & & 19.8 & \\
\hline Corn gluten meal & & 62.3 & & 62.3 & & 10.0 & & 10.0 & \\
\hline Corn starch & & 0.0 & & 100. & & 0.0 & & 100.0 & \\
\hline Soy oil & & 105.3 & & 19.2 & & 105.8 & & 19.7 & \\
\hline Diamol & & 147.1 & & 2.9 & & 148.7 & & 4.8 & \\
\hline Premix (wheat) ${ }^{2}$ & & 5.0 & & 5.0 & & 5.0 & & 5.0 & \\
\hline Limestone fine & & 9.4 & & 9.6 & & 9.2 & & 9.4 & \\
\hline Mono-Calcium Phosphate & & 6.9 & & 6.8 & & 7.4 & & 7.2 & \\
\hline Salt & & 1.4 & & 0.6 & & 0.9 & & 0.1 & \\
\hline Sodium bicarbonate & & 3.3 & & 4.3 & & 4.0 & & 5.0 & \\
\hline Potassium chloride & & 0.0 & & 0.5 & & 0.0 & & 0.5 & \\
\hline $\mathrm{TiO} 2$ & & 0.0 & & $0 . c$ & & 0.0 & & 0.0 & \\
\hline L-Lysine $\mathrm{HCl}$ & & 4.3 & & 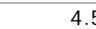 & & 5.7 & & 6.5 & \\
\hline DL-Methionine & & 2.4 & & 2.3 & & 3.8 & & 3.7 & \\
\hline L-Threonine & & 1.0 & & 1.2 & & 2.5 & & 2.7 & \\
\hline m2389-Valine & & 9.7 & & 10.2 & & 26.2 & & 27.9 & \\
\hline L-Arginine & & 2.2 & & 2.8 & & 3.5 & & 4.1 & \\
\hline L-I soleucine & & 0.1 & & 0.2 & & 1.7 & & 2.0 & \\
\hline L-Tryptophan & & 0.0 & & $0 . c$ & & 0.2 & & 0.4 & \\
\hline m2313 Clinacox & & 5.0 & & $5 .($ & & 5.0 & & 5.0 & \\
\hline m2713 Lys/Tryp/Px & & 0.0 & & 2.3 & & 0.0 & & 0.0 & \\
\hline m2342/Glu-Xyl & & 2.5 & & 2.5 & & 2.5 & & 2.5 & \\
\hline m2345 EC-Phytase Tj1 & & 1.3 & & 1.3 & & 1.3 & & 1.3 & \\
\hline m2345 EC-Phytase Tj2 & & 2.0 & & $2 .($ & & 2.0 & & 2.0 & \\
\hline Nutrient & & Calc. & Ana. & Calc. & Ana. & Calc. & Ana. & Calc. & Ana. \\
\hline DM & & 901 & 920 & 879 & 895 & 899 & 907 & 876 & 896 \\
\hline ASH & & 178 & 163 & 41 & 40 & 179 & 167 & 42 & 43 \\
\hline $\mathrm{CP}$ & & 200 & 201 & 200 & 195 & 170 & 171 & 170 & 168 \\
\hline CFATh & & 125 & 128 & 45 & 49 & 125 & 123 & 45 & 50 \\
\hline Cfib & & 18 & 19 & 20 & 17 & 19 & 19 & 21 & 18 \\
\hline STARCHEwers & & 270 & 314 & 448 & 505 & 293 & 343 & 471 & 528 \\
\hline SUG & & 27 & 24 & 26 & 25 & 28 & 27 & 27 & 25 \\
\hline $\mathrm{Ca}$ & & 5.4 & 6.8 & 5.4 & 6.0 & 5.4 & 6.7 & 5.4 & 6.3 \\
\hline $\mathrm{P}$ & & 4.1 & 4.8 & 4.2 & 4.4 & 4.1 & 4.6 & 4.2 & 4.4 \\
\hline $\mathrm{OP}$ & & 3.2 & & 3.2 & & 3.2 & & 3.2 & \\
\hline bCa : oP & & 2.2 & & 2.2 & & 2.2 & & 2.2 & \\
\hline $\mathrm{Mg}$ & & 1.0 & & 1.1 & & 1.0 & & 1.1 & \\
\hline $\mathrm{K}$ & & 5.8 & 6.8 & 5.8 & 5.8 & 5.8 & 6.8 & 5.8 & 5.7 \\
\hline $\mathrm{Na}$ & & 1.5 & 1.9 & 1.5 & 1.6 & 1.5 & 1.9 & 1.5 & 1.5 \\
\hline $\mathrm{Cl}$ & & 2.2 & 2.6 & 2.2 & 2.7 & 2.2 & 2.9 & 2.2 & 2.9 \\
\hline $\mathrm{EB}, \mathrm{meq}$ & & 155 & & 155 & & 155 & & 154 & \\
\hline MEbroiler, kcal & & 2975 & & 2975 & & 2975 & & 2975 & \\
\hline LYS & & 12.3 & & 12.2 & & 12.1 & & 12.1 & \\
\hline $\mathrm{dLYS}$ & & 11.2 & & 11.2 & & 11.2 & & 11.2 & \\
\hline dMET & & 5.5 & & 5.5 & & 6.0 & & 6.0 & \\
\hline $\mathrm{dCYS}$ & & 2.6 & & 2.7 & & 2.1 & & 2.2 & \\
\hline $\mathrm{dMET}+\mathrm{CYS}$ & & 8.2 & & 8.2 & & 8.2 & & 8.2 & \\
\hline dVAL & & 9.1 & & 9.0 & & 9.0 & & 9.0 & \\
\hline dARG & & 11.8 & & 11.8 & & 11.8 & & 11.8 & \\
\hline dILE & & 7.3 & & 7.4 & & 7.3 & & 7.4 & \\
\hline dTHR & & 7.3 & & 7.3 & & 7.3 & & 7.3 & \\
\hline dTRP & & 1.8 & & 1.8 & & 1.7 & & 1.8 & \\
\hline $\mathrm{dGLY}$ & & 5.9 & & 5.8 & & 5.0 & & 4.8 & \\
\hline dSER & & 8.6 & & 8.4 & & 6.6 & & 6.4 & \\
\hline dLEU & & 16.8 & & 17.2 & & 11.5 & & 11.9 & \\
\hline $\mathrm{dPHE}$ & & 9.0 & & 8.8 & & 6.7 & & 6.6 & \\
\hline dTYR & & 6.9 & & 6.8 & & 4.9 & & 4.8 & \\
\hline dALA & & 8.9 & & 9.2 & & 6.2 & & 6.4 & \\
\hline dASP & & 15.2 & & 14.2 & & 12.3 & & 11.3 & \\
\hline $\mathrm{dGLU}$ & & 32.4 & & 31.9 & & 26.1 & & 25.6 & \\
\hline dPRO & & 11.4 & & 11.7 & & 8.7 & & 9.0 & \\
\hline
\end{tabular}

${ }^{1}$ HP (high protein), LP (low protein), HF (high fat), LF (low fat).

2 Composition of premix: 12,000 IE retinol, 2,400 IE cholecalciferol, $50 \mathrm{mg}$ dl-a-tocopherol, $1.5 \mathrm{mg}$ menadione, $2.0 \mathrm{mg}$ thiamine, $7.5 \mathrm{mg}$ riboflavin, $3.5 \mathrm{mg}$ pyridoxine- $\mathrm{HCl}, 25 \mu \mathrm{g}$ cyanocobalamine, $35 \mathrm{mg}$ niacin, $12 \mathrm{mg} \mathrm{D}$-pantothenic acid, $460 \mathrm{mg}$ choline chloride, $1.0 \mathrm{mg}$ folic acid, $0.2 \mathrm{mg}$ biotin, $86 \mathrm{mg}$ iron, $12 \mathrm{mg}$ copper, $85 \mathrm{mg}$ manganese, $60 \mathrm{mg}$ zinc, $0.8 \mathrm{mg}$ iodine, $0.15 \mathrm{mg}$ selenium, $125 \mathrm{mg}$ anti-oxidant. 
Table $\mathbf{2 b} \quad$ Ingredient and nutrient composition of experimental finisher diets in $\mathrm{g} / \mathrm{kg}$ unless stated otherwise (29-38 d of age)

\begin{tabular}{|c|c|c|c|c|c|c|c|c|c|}
\hline & $\begin{array}{l}\text { Unit/ } \\
\text { kg }\end{array}$ & HP-HF ${ }^{1}$ & & HP-LF ${ }^{1}$ & & LP-HF ${ }^{1}$ & & $L P-L^{1}$ & \\
\hline \multicolumn{10}{|l|}{ Feed ingredient } \\
\hline Corn & & 223.7 & & 384.7 & & 264.0 & & 420.3 & \\
\hline Wheat & & 225.0 & & 225.0 & & 225.0 & & 225.0 & \\
\hline Soybean meal & & 163.3 & & 127.7 & & 163.4 & & 128.5 & \\
\hline Potato protein (Promyl FF) & & 30.0 & & 30.0 & & 10.0 & & 10.0 & \\
\hline Corn gluten meal & & 50.0 & & 50.0 & & 1.0 & & 1.0 & \\
\hline Corn starch & & 0.0 & & 100.0 & & 0.0 & & 100.0 & \\
\hline Soy oil & & 105.3 & & 19.1 & & 105.8 & & 19.7 & \\
\hline Diamol & & 146.2 & & 2.4 & & 147.3 & & 2.5 & \\
\hline Premix (wheat) ${ }^{2}$ & & 5.0 & & 5.0 & & 5.0 & & 5.0 & \\
\hline Limestone fine & & 8.7 & & 8.9 & & 8.5 & & 8.7 & \\
\hline Mono-Calcium Phosphate & & 5.0 & & 4.8 & & 5.4 & & 5.2 & \\
\hline Salt & & 0.9 & & 0.2 & & 5.0 & & 0.0 & \\
\hline Sodium bicarbonate & & 3.5 & & 4.6 & & 4.2 & & 4.8 & \\
\hline Potassium chloride & & 0.5 & & 1.0 & & 0.5 & & 0.6 & \\
\hline $\mathrm{TiO2}$ & & 5.0 & & 5.0 & & 5.0 & & 5.0 & \\
\hline L-Lysine $\mathrm{HCl}$ & & 4.4 & & 5.2 & & 6.0 & & 4.8 & \\
\hline DL-Methionine & & 2.5 & & 2.4 & & 3.9 & & 3.8 & \\
\hline L-Threonine & & 1.3 & & 1.5 & & 2.8 & & 3.0 & \\
\hline m2389-Valine & & 11.2 & & 13.0 & & 29.9 & & 31.5 & \\
\hline L-Arginine & & 2.3 & & 2.9 & & 3.7 & & 4.2 & \\
\hline L-Isoleucine & & 0.4 & & 0.7 & & 2.1 & & 2.4 & \\
\hline L-Tryptophan & & 0.0 & & 0.2 & & 0.3 & & 0.0 & \\
\hline m2713 Lys/Tryp/Px & & 0.0 & & 0.0 & & 0.0 & & 8.3 & \\
\hline m2342/Glu-Xyl & & 2.5 & & 2.5 & & 2.5 & & 2.5 & \\
\hline m2345 EC-Phytase Tj1 & & 1.3 & & 1.3 & & 1.3 & & 1.3 & \\
\hline m2345 EC-Phytase Tj2 & & 2.0 & & 2.0 & & 2.0 & & 2.0 & \\
\hline Nutrient & & Calc. & Ana. & Calc. & Ana. & Calc. & Ana. & Calc. & Ana. \\
\hline DM & & 900 & 918 & 878 & 899 & 898 & 917 & 876 & 906 \\
\hline ASH & & 179 & 160 & 42 & 48 & 180 & 164 & 42 & 43 \\
\hline $\mathrm{CP}$ & & 190 & 187 & 190 & 185 & 160 & 158 & 160 & 158 \\
\hline CFATh & & 125 & 116 & 45 & 49 & 125 & 118 & 45 & 44 \\
\hline Cfib & & 18 & 20 & 20 & 19 & 19 & 21 & 22 & 22 \\
\hline STARCHEwers & & 278 & 313 & 456 & 485 & 301 & 341 & 479 & 523 \\
\hline SUG & & 27 & 27 & 26 & 26 & 28 & 28 & 28 & 28 \\
\hline $\mathrm{Ca}$ & & 4.8 & 5.7 & 4.8 & 5.8 & 4.8 & 5.9 & 4.8 & 5.8 \\
\hline $\mathrm{P}$ & & 3.6 & 4.3 & 3.7 & 4.5 & 3.6 & 4.5 & 3.7 & 4.5 \\
\hline $\mathrm{OP}$ & & 2.8 & & 2.8 & & 2.8 & & 2.8 & \\
\hline $\mathrm{bCa}: \mathrm{oP}$ & & 2.3 & & 2.3 & & 2.3 & & 2.3 & \\
\hline $\mathrm{Mg}$ & & 1.0 & & 1.0 & & 1.0 & & 1.1 & \\
\hline $\mathrm{K}$ & & 6.0 & 7.0 & 6.0 & 6.0 & 6.0 & 6.9 & 5.9 & 5.9 \\
\hline $\mathrm{Na}$ & & 1.4 & 1.7 & 1.4 & 1.4 & 1.4 & 1.7 & 1.4 & 1.5 \\
\hline $\mathrm{Cl}$ & & 2.2 & 2.6 & 2.2 & 2.7 & 2.2 & 2.9 & 2.2 & 2.9 \\
\hline $\mathrm{EB}, \mathrm{meq}$ & & 155 & & 155 & & 155 & & 152 & \\
\hline MEbroiler, kcal & & 2975 & & 2975 & & 2975 & & 2975 & \\
\hline LYS & & 11.9 & & 11.9 & & 11.7 & & 11.7 & \\
\hline dLYS & & 10.9 & & 10.9 & & 10.9 & & 10.9 & \\
\hline dMET & & 5.4 & & 5.3 & & 5.9 & & 5.8 & \\
\hline dCYS & & 2.5 & & 2.5 & & 2.0 & & 2.0 & \\
\hline $\mathrm{dMET}+\mathrm{CYS}$ & & 7.9 & & 7.9 & & 7.9 & & 7.9 & \\
\hline dVAL & & 8.7 & & 8.7 & & 8.7 & & 8.7 & \\
\hline dARG & & 11.4 & & 11.4 & & 11.4 & & 11.4 & \\
\hline dILE & & 7.2 & & 7.2 & & 7.2 & & 7.2 & \\
\hline dTHR & & 7.1 & & 7.1 & & 7.1 & & 7.1 & \\
\hline dTRP & & 1.7 & & 1.8 & & 1.7 & & 1.7 & \\
\hline dGLY & & 5.6 & & 5.5 & & 4.6 & & 4.5 & \\
\hline dSER & & 8.0 & & 7.8 & & 6.0 & & 5.8 & \\
\hline dLEU & & 15.5 & & 15.9 & & 10.2 & & 10.6 & \\
\hline $\mathrm{dPHE}$ & & 8.4 & & 8.3 & & 6.1 & & 5.9 & \\
\hline dTYR & & 6.4 & & 6.2 & & 4.4 & & 4.2 & \\
\hline dALA & & 8.2 & & 8.5 & & 5.5 & & 5.8 & \\
\hline dASP & & 14.4 & & 13.4 & & 11.4 & & 10.4 & \\
\hline dGLU & & 30.9 & & 30.3 & & 24.8 & & 24.3 & \\
\hline dPRO & & 10.8 & & 11.1 & & 8.1 & & 8.4 & \\
\hline $\mathrm{dPRO}$ & & 10.8 & & 11.1 & & 8.1 & & 8.4 & \\
\hline
\end{tabular}

1 HP (high protein), LP (low protein), HF (high fat), LF (low fat).

${ }^{2}$ Composition of premix: 12,000 IE retinol, 2,400 IE cholecalciferol, $50 \mathrm{mg}$ dl-a-tocopherol, $1.5 \mathrm{mg}$ menadione, $2.0 \mathrm{mg}$ thiamine, $7.5 \mathrm{mg}$ riboflavin, $3.5 \mathrm{mg}$ pyridoxine- $\mathrm{HCl}, 25 \mu \mathrm{g}$ cyanocobalamine, $35 \mathrm{mg}$ niacin, $12 \mathrm{mg} \mathrm{D}$-pantothenic acid, $460 \mathrm{mg}$ choline chloride, $1.0 \mathrm{mg}$ folic acid, $0.2 \mathrm{mg}$ biotin, $86 \mathrm{mg}$ iron, $12 \mathrm{mg}$ copper, $85 \mathrm{mg}$ manganese, $60 \mathrm{mg}$ zinc, $0.8 \mathrm{mg}$ iodine, $0.15 \mathrm{mg}$ selenium, $125 \mathrm{mg}$ anti-oxidant. 


\subsection{Housing and management}

In total, 6480 Ross 308 broilers (males) were used in the study and were placed in floor pens. A natural ventilated broiler house was used in which 3 rows of 12 floor pens $(4.45 \times 3.14 \mathrm{~m})$ were installed. Each row was divided in two blocks. In each floor pen 180 day-old broilers were placed. The housing management, feeding and husbandry conditions are regarded as representative for a modern commercial operation in Europe. Day-old broilers were distributed among the 36 floor pens bedded with wood shavings $\left(0.9 \mathrm{~kg} / \mathrm{m}^{2}\right)$. On the day of arrival, 500 broilers were weighed to determine the mean start weight of the broilers. After weighing, 3 times 60 broilers were placed in each floor pen. Water and feed was ad libitum available for the broilers. Feed was supplied automatically via a feed bin and 5 feeders per floor pen. Water was available via 30 drinking nipples per floor pen. The climate was controlled automatically and heating was controlled by floor heating and an additional heater. Three fans were installed to distribute the heat through the entire building equally. Ventilation was controlled via ventilation fans in the wall at the backside of the building. One day prior to placement of the broilers the rooms were pre-heated to $33-35^{\circ} \mathrm{C}$. Temperature was decreased gradually to $22^{\circ} \mathrm{C}$ at 25 days of age. Lighting was provided via TL-tubes. The lighting schedule was 20 hours light and 4 hours dark. Light intensity was decreased gradually to 5/10 lux at 11-14 days of age. From 14 days onwards the lighting schedule was 16 hours light and 8 hours dark. Visual observation of the birds was done several times per day to check animal health. Day-old broilers were vaccinated against IB (Infectious Bronchitis) at the hatchery, NewCastle Disease at 14 days of age and Gumboro at 17 days of age.

\subsection{Observations during the study}

- $\quad$ Prior to feed formulation, main feed ingredients were analysed for dry matter, crude fath, starch $_{a m}$ and sugars in order to formulate the experimental diets accurately according to calculations.

- Experimental diets were chemically analysed in duplo for concentration of dry matter, crude protein $(\mathrm{N} \times 6.25)$, crude fath, crude fiber, crude ash, starcham and sugars. Minerals calcium, phosphorus, sodium, chloride and potassium were also chemically analysed in duplo.

- $\quad$ Feed intake was determined per pen at 8, 28 and 38 days of age.

- Body weight of broilers was determined per pen by an automatic weighing system and group weighings were conducted at 38 days of age to determine the final body weight per pen.

- At 37 days of age, 10 broilers with a body weight corresponding to the mean body weight of the pen were selected and were delivered to an experimental slaughter plant to determine carcass yields (griller, breast meat, wings, thighs, legs and remaining carcass.

- Litter quality (score 1 to $5 ; 1=$ dry and friable and $5=$ wet and crusty) and dirtiness of feathers (score 1 to $5 ; 1=$ clean and 5=dirty) were scored twice a week from 14 days of age onwards.

- $\quad$ Foot pad quality (score 0 to 2; $0=$ no lesion, $2=$ severe lesion) of 8 randomly selected broilers per pen was scored on 17, 29 and 38 days of age. All eight selected broilers were scored a 0 , 1 or 2 and the average score per pen was calculated.

- Two broilers per pen with a body weight close to the mean body weight per pen were selected at $8,18,28$ and 37 days of age. The selected broilers were anaesthetized and subsequently euthanized by an intravenous injection of T61 (Intervet Int.). Subsequently, the chest cavity and the abdomen were opened and the gastro-intestinal tract was ligated and removed from the bird. The content of the gastro-intestinal tract was removed and the empty gastrointestinal tract was put together with the carcass. The two carcasses with empty gastrointestinal tract were frozen $\left(-20^{\circ} \mathrm{C}\right)$ per pen and were considered as one pooled sample per pen. The carcasses and gastro-intestinal tract samples were autoclaved and homogenized in a mixer and a sample was taken to analyse body composition: dry matter (ANAL-10066 ISO 1442), crude protein (ANAL- 10005 NEN-ISO 937), crude fat (ANAL-10112 ISO 1443) and crude ash (ANAL-10028 NEN-ISO 936).

- Excreta from the colon was collected in two anaesthetized and euthanized broilers per pen at 37 days of age for determination of nutrient digestibility. Excreta samples of three pens within a treatment were pooled before chemical analysis. Nutrient digestibility was determined in pooled samples for dry matter (DM), organic matter (OM), crude protein (CP), crude fat (FAT) and starch + sugars digestibility. 


\section{$2.6 \quad$ Statistics}

Response parameters were statistically analysed by ANOVA using GenStat statistical software (16th edition, VSN International Ltd., Hemel Hempstead, UK), using series of six pens situated next to each other as block factor, dietary protein concentration, dietary fat/starch concentration and the interaction between dietary protein concentration and dietary fat/starch concentration as explanatory variables according to the statistical model:

$\mathrm{Y}=\mu+$ block $_{\mathrm{i}}+$ dietary protein concentration $\mathrm{j}_{\mathrm{j}}+$ dietary fat/starch concentration $_{\mathrm{k}}+\mathrm{e}_{\mathrm{ijkl}}$

Where:

Y

$\mu$

block

dietary protein concentration

dietary fat/starch concentration

error
$=$ Response parameter

$=$ General mean

$=$ Block ( six pens situated next to each other in a row) $(i=1 . .6)$

$=$ Effect of dietary protein concentration $(j=1,2)$

$=$ Effect of dietary fat/starch concentration $(k=1 . .3)$

$=$ Error term

Mortality, litter quality and foot pad quality data were log-transformed prior to statistical analysis. The P-value of the treatment effect and the LSD (least significant difference $(P=0.05)$ ) were provided per response parameter. Treatment effects with a P-value $\leq 0.05$ were considered to be statistically significant. 


\section{Results and Discussion}

The experiment was conducted according to the protocol without major problems or relevant deviations. Day-old broilers arrived healthy and mean body weight at arrival was $44 \mathrm{~g}$. The experimental period started at 8 days of age and mean body weight of the male broilers was $198 \mathrm{~g}$, which was according to the performance standards of Aviagen (breeder organization of brand Ross 308) (Aviagen, 2014). Overall, mortality during the growing period from 0 to 38 days of age was $1.9 \%$ and no specific cause of mortality was observed.

\subsection{Growth performance}

Growth performance results for the growth periods 8 to 28 and 29 to $38 \mathrm{~d}$ of age are reported in Appendix 2 and 3, respectively. Growth performance results over the period of 0 to 38 days of age are presented in Table 3.

Table 3 Growth performance of broilers over the period 0 to $38 \mathrm{~d}$ of age

\begin{tabular}{|c|c|c|c|c|c|c|}
\hline & & BW 38d & BW gain & FCR & $\begin{array}{l}\text { Feed } \\
\text { intake }\end{array}$ & Mortality \\
\hline & & g & g/d & & $g / d$ & $\%$ \\
\hline \multicolumn{7}{|l|}{ Protein } \\
\hline High & & $2264^{a}$ & $59.6^{a}$ & $1.65^{b}$ & 98.3 & 1.9 \\
\hline Low & & $2214^{b}$ & $58.3^{b}$ & $1.68^{a}$ & 98.1 & 1.9 \\
\hline \multicolumn{7}{|l|}{ Fat } \\
\hline High & & $2102^{c}$ & $55.3^{c}$ & $1.74^{\mathrm{a}}$ & $96.3^{b}$ & 1.4 \\
\hline Medium & & $2256^{b}$ & $59.4^{b}$ & $1.69^{b}$ & $100.5^{a}$ & 2.1 \\
\hline Low & & $2360^{a}$ & $62.1^{a}$ & $1.57^{c}$ & $97.8^{b}$ & 2.2 \\
\hline Protein & Fat & & & & & \\
\hline High & High & 2117 & 55.7 & 1.71 & 95.4 & 1.4 \\
\hline High & Medium & 2288 & 60.2 & 1.67 & 101.0 & 2.3 \\
\hline High & Low & 2386 & 62.8 & 1.57 & 98.5 & 2.1 \\
\hline Low & High & 2086 & 54.9 & 1.77 & 97.3 & 1.3 \\
\hline Low & Medium & 2224 & 58.5 & 1.71 & 100.1 & 2.0 \\
\hline Low & Low & 2333 & 61.4 & 1.57 & 97.0 & 2.3 \\
\hline \multicolumn{7}{|l|}{ P-values } \\
\hline Protein & & $<0.001$ & $<0.001$ & 0.037 & 0.800 & 0.914 \\
\hline Fat & & $<0.001$ & $<0.001$ & $<0.001$ & $<0.001$ & 0.250 \\
\hline Protein $\times$ Fat & & 0.510 & 0.510 & 0.227 & 0.098 & 0.902 \\
\hline
\end{tabular}

Feed intake of the birds fed HP diets was not different from feed intake of broilers fed LP diets. Body weight gain of broilers fed HP diets was significantly higher than body weight gain of broilers fed LP diets (59.6 vs. $58.3 \mathrm{~g} ; \mathrm{P}<0.001$ ). Feed conversion ratio of birds fed HP diets was significantly lower than feed conversion ratio of broilers fed LP diets ( 1.65 vs. 1.68; $P=0.037$ ). Despite a higher inclusion level of free essential amino acids in LP diets in order to meet apparent faecal digestible amino acid concentrations 10\% higher than CVB (2012) recommendations, growth performance of birds fed LP diets was lower than on HP diets. However, the difference in feed conversion ratio between broilers fed HP and LP diets was in the second experiment smaller than in the first experiment. The difference in FCR between HP and LP diets in experiment 2 was 0.03 whereas in experiment 1 the difference in FCR was 0.08 . The concentration of non-essential amino acids in LP diets related to the $30 \mathrm{~g} / \mathrm{kg}$ lower crude protein concentration may still have been limiting body weight gain in LP diets compared to HP diets.

Feed intake of birds fed medium fat (MF) diets was significantly higher than feed intake of birds fed low fat $(L F)$ and high fat $(H F)$ diets $(P<0.001)$. The reason for the difference in feed intake of birds fed MF diets compared to birds fed LF and HF diets is not clear as the MF diet is a 50/50 mixture of the LF and HF diet. Body weight gain of broilers increased as starch concentration in the diet increased (HF: 
$55.3 \mathrm{~g} / \mathrm{d}$, MF: $59.5 \mathrm{~g} / \mathrm{d}$ and LF: $62.1 \mathrm{~g} / \mathrm{d}$; $\mathrm{P}<0.001$ ). Feed conversion ratio of broilers decreased significantly as starch concentration in the diet increased (HF: 1.74, MF: 1.69 , LF: $1.57 ; \mathrm{P}<0.001$ ). In the first experiment the effect on FCR was more pronounced in LP diets than in HP diets but in the second experiment no interaction effect has been observed. From the second experiment it can be concluded that exchange of dietary fat by starch in MF and LF diets resulted in a significantly higher body weight gain and significantly lower FCR. Camp et al. (2003) studied the effect of sucrose on growth performance in pigs and also found a higher body weight gain and lower feed conversion ratio by higher inclusion levels of sucrose in diets for growing-finishing pigs. Mortality in broilers was not affected by dietary protein concentration in the second experiment whereas in the first experiment LP diets resulted in a significantly lower mortality than HP diets.

\subsection{Carcass yields}

Carcass yields in broilers determined at 38 days of age are presented in Table 4.

Table 4 Carcass yields in broilers at 38 days of age

\begin{tabular}{|c|c|c|c|c|c|c|}
\hline & & BW 38 d & Griller & $\begin{array}{c}\text { Breast } \\
\text { meat }\end{array}$ & Legs & Wings \\
\hline & & g] & $\%$ & $\%$ & $\%$ & $\%$ \\
\hline \multicolumn{7}{|l|}{ Protein } \\
\hline High & & 2194 & $63.7^{a}$ & $28.9^{a}$ & $41.4^{\mathrm{b}}$ & $10.8^{a}$ \\
\hline Low & & 2205 & $62.5^{b}$ & $27.3^{b}$ & $43.0^{a}$ & $10.5^{b}$ \\
\hline \multicolumn{7}{|l|}{ Fat } \\
\hline High & & $2044^{c}$ & $62.4^{\mathrm{b}}$ & $26.7^{c}$ & $42.7^{a}$ & $10.9^{a}$ \\
\hline Medium & & $2240^{b}$ & $62.9^{b}$ & $28.2^{b}$ & $42.6^{a}$ & $10.6^{\mathrm{ab}}$ \\
\hline Low & & $2314^{a}$ & $64.0^{a}$ & $29.5^{a}$ & $41.3^{b}$ & $10.4^{\mathrm{b}}$ \\
\hline Protein & Fat & & & & & \\
\hline High & High & 2014 & 63.0 & 27.3 & 41.9 & 11.1 \\
\hline High & Medium & 2235 & 63.6 & 29.1 & 41.6 & 10.6 \\
\hline High & Low & 2333 & 64.4 & 30.3 & 40.6 & 10.6 \\
\hline Low & High & 2074 & 61.8 & 26.1 & 43.5 & 10.6 \\
\hline Low & Medium & 2245 & 62.1 & 27.2 & 43.6 & 10.7 \\
\hline Low & Low & 2295 & 63.7 & 28.7 & 42.0 & 10.3 \\
\hline \multicolumn{7}{|l|}{ P-values } \\
\hline $\begin{array}{l}\text { Protein } \\
\text { Fat }\end{array}$ & & $\begin{array}{r}0.599 \\
<\mathbf{0 . 0 0 1}\end{array}$ & $\begin{array}{r}0.001 \\
<0.001\end{array}$ & $\begin{array}{l}<0.001 \\
<0.001\end{array}$ & $\begin{array}{l}<0.001 \\
<0.001\end{array}$ & $\begin{array}{l}0.064 \\
0.012\end{array}$ \\
\hline Protein $\times$ Fat & & 0.177 & 0.592 & 0.776 & 0.490 & 0.093 \\
\hline
\end{tabular}

Carcass yields showed that broilers fed HP diets had a higher percentage griller and a higher breast meat and wing yield than broilers fed LP diets. Leg yield was lower in broilers fed HP diets.

Substitution of fat by starch in the diets resulted in a higher final body weight of broilers (2044, 2240 and $2314 \mathrm{~g}$, respectively; $\mathrm{P}<0.001$ ). The higher starch concentration in LF diets resulted in a higher percentage griller and a higher breast meat yield and a lower leg and wing yield than in MF and HF diets. 


\subsection{Body composition}

Two broilers per pen with a body weight close to the mean body weight per pen were selected at 8 , 18, 28 and 37 days of age to determine body composition for dry matter (DM), ash, crude protein (CP) and fat (Fat). The deposition of DM, Ash, CP and Fat in the periods from 8 to 18,18 to 28 and 28 to 37 days was calculated for these periods. In Table 5 to 8 the chemical body composition of broilers at $8,18,28$ and $37 \mathrm{~d}$ of age is presented. The deposition of $\mathrm{CP}$ and Fat in the periods from 8 to 18,18 to 28 and 28 to 37 days is presented in Table 9.

Table 5 Chemical body composition (dry matter (DM), ash (Ash), crude protein (CP) and crude fat (Fat)) at $8 \mathrm{~d}$ of age ( $\mathrm{g} / \mathrm{kg}$ body weight)

\begin{tabular}{|c|c|c|c|c|c|}
\hline & & DM & Ash & $\mathrm{CP}$ & Fat \\
\hline & & $\mathrm{g} / \mathrm{kg}$ & $\mathrm{g} / \mathrm{kg}$ & $\mathrm{g} / \mathrm{kg}$ & $\mathrm{g} / \mathrm{kg}$ \\
\hline \multicolumn{6}{|l|}{ Protein } \\
\hline High & & 257 & 19.3 & 145 & 96 \\
\hline Low & & 259 & 19.2 & 146 & 95 \\
\hline \multicolumn{6}{|l|}{ Fat } \\
\hline High & & 259 & $19.6^{a}$ & 147 & 96 \\
\hline Medium & & 255 & $18.9^{b}$ & 144 & 95 \\
\hline Low & & 260 & $19.2^{\mathrm{ab}}$ & 146 & 97 \\
\hline Protein & Fat & & & & \\
\hline High & High & 259 & 19.5 & 146 & 97 \\
\hline High & Medium & 254 & 19.0 & 144 & 94 \\
\hline High & Low & 259 & 19.3 & 145 & 97 \\
\hline Low & High & 259 & 19.8 & 147 & 94 \\
\hline Low & Medium & 256 & 18.8 & 144 & 95 \\
\hline Low & Low & 261 & 19.0 & 146 & 96 \\
\hline \multicolumn{6}{|l|}{ P-values } \\
\hline Protein & & 0.643 & 0.904 & 0.808 & 0.758 \\
\hline Fat & & 0.273 & 0.042 & 0.170 & 0.742 \\
\hline Protein $x$ Fat & & 0.918 & 0.478 & 0.960 & 0.736 \\
\hline
\end{tabular}

Until 8 days of age, broilers in all experimental groups received a similar commercial starter diet. No differences in chemical composition were observed between dietary treatments (Table 5) except a lower Ash content in broilers fed the MF diet compared with broilers fed the HF diet. This difference in Ash content cannot be explained by dietary treatment until 8 days of age as a commercial diet was supplied to all experimental groups. 
Table 6 Chemical body composition (dry matter (DM), ash (Ash), crude protein (CP) and crude fat (Fat)) at $18 \mathrm{~d}$ of age ( $\mathrm{g} / \mathrm{kg}$ body weight)

\begin{tabular}{|c|c|c|c|c|c|}
\hline & & $\begin{array}{r}\text { DM } \\
18 \mathrm{~d} \\
\mathrm{~g} / \mathrm{kg}\end{array}$ & $\begin{array}{c}\text { Ash } \\
18 \mathrm{~d} \\
\mathrm{~g} / \mathrm{kg}\end{array}$ & $\begin{array}{r}\mathrm{CP} \\
18 \mathrm{~d} \\
\mathrm{~g} / \mathrm{kg}\end{array}$ & $\begin{array}{r}\text { Fat } \\
18 \mathrm{~d} \\
\mathrm{~g} / \mathrm{kg}\end{array}$ \\
\hline \multicolumn{6}{|l|}{ Protein } \\
\hline High & & $299^{b}$ & 20.5 & 160 & $121^{b}$ \\
\hline Low & & $309^{a}$ & 21.2 & 158 & $130^{a}$ \\
\hline \multicolumn{6}{|l|}{ Fat } \\
\hline High & & $296^{b}$ & 20.5 & 160 & $119^{b}$ \\
\hline Medium & & $307^{a}$ & 20.6 & 159 & $128^{a}$ \\
\hline Low & & $309^{a}$ & 21.4 & 158 & $129^{a}$ \\
\hline Protein & Fat & & & & \\
\hline High & High & 292 & 20.1 & 161 & 116 \\
\hline High & Medium & 299 & 20.1 & 160 & 121 \\
\hline High & Low & 306 & 21.2 & 160 & 125 \\
\hline Low & High & 300 & 21.0 & 160 & 123 \\
\hline Low & Medium & 314 & 21.0 & 159 & 135 \\
\hline Low & Low & 312 & 21.6 & 156 & 134 \\
\hline \multicolumn{6}{|l|}{ P-values } \\
\hline Protein & & $<0.001$ & 0.078 & 0.115 & $<0.001$ \\
\hline Fat & & $<0.001$ & 0.137 & 0.312 & $<0.001$ \\
\hline Protein $\times$ Fat & & 0.279 & 0.820 & 0.332 & 0.359 \\
\hline
\end{tabular}

At 18 days of age, differences in chemical composition were observed between dietary treatments (Table 6). Dry matter and Fat content in broilers fed HP diets was significantly lower than in broilers fed LP diets. Content of Ash and CP was not affected by dietary protein concentration. Dry matter and Fat content in broilers fed HF diets was lower than in broilers fed MF and LF diets. Ash and CP content were not affected by dietary fat/starch concentration. 
Table 7 Chemical body composition (dry matter (DM), ash (Ash), crude protein (CP) and crude fat (Fat)) at $28 \mathrm{~d}$ of age ( $\mathrm{g} / \mathrm{kg}$ body weight)

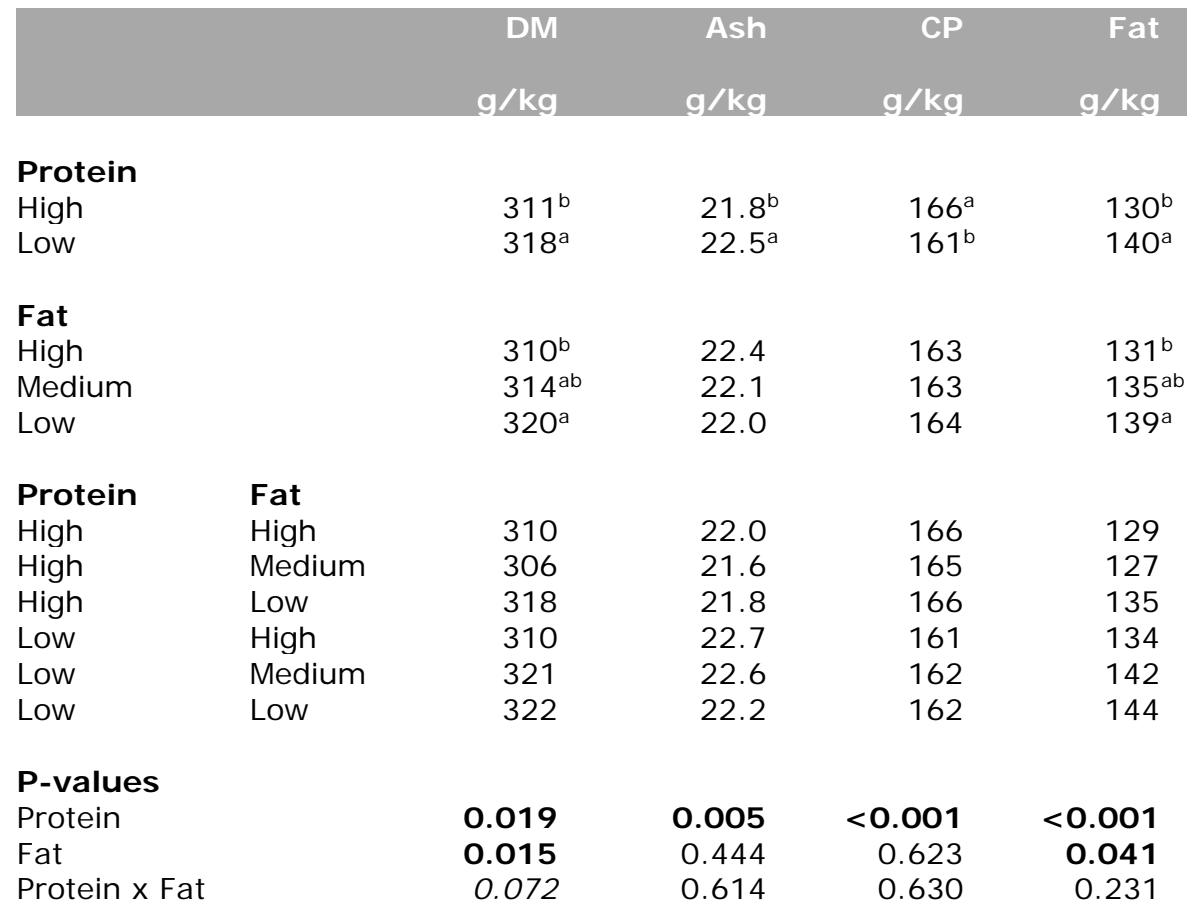

At 28 days of age, differences in chemical composition were observed between dietary treatments (Table 7). Dry matter, Ash and Fat content in broilers fed HP diets was significantly lower than in broilers fed LP diets. Content of CP in broilers fed HP diets was significantly higher than in broilers fed LP diets. Dry matter and Fat content in broilers fed HF diets was lower than in broilers fed LF diets. Ash and CP content were not affected by dietary fat/starch concentration. 
Table 8 Chemical body composition (dry matter (DM), ash (Ash), crude protein (CP) and crude fat (Fat)) at $37 \mathrm{~d}$ of age ( $\mathrm{g} / \mathrm{kg}$ body weight)

\begin{tabular}{|c|c|c|c|c|c|}
\hline & & $\begin{array}{r}\text { DM } \\
37 \mathrm{~d} \\
\mathrm{~g} / \mathrm{kg}\end{array}$ & $\begin{array}{l}\text { Ash } \\
37 \mathrm{~d} \\
\mathrm{~g} / \mathrm{kg}\end{array}$ & $\begin{array}{r}\text { CP } \\
37 \text { d } \\
\mathrm{g} / \mathrm{kg}\end{array}$ & $\begin{array}{l}\text { Fat } \\
37 \mathrm{~d} \\
\mathrm{~g} / \mathrm{kg}\end{array}$ \\
\hline \multicolumn{6}{|l|}{ Protein } \\
\hline High & & $326^{b}$ & $22.2^{b}$ & $173^{a}$ & $136^{b}$ \\
\hline Low & & $332^{a}$ & $23.4^{a}$ & $168^{b}$ & $146^{\circ}$ \\
\hline \multicolumn{6}{|l|}{ Fat } \\
\hline High & & 329 & 23.0 & 171 & 141 \\
\hline Medium & & 327 & 22.4 & 170 & 141 \\
\hline Low & & 332 & 23.1 & 170 & 141 \\
\hline Protein & Fat & & & & \\
\hline High & High & 325 & 22.0 & 173 & 136 \\
\hline High & Medium & 324 & 22.0 & 173 & 134 \\
\hline High & Low & 330 & 22.6 & 171 & 138 \\
\hline Low & High & 332 & 23.9 & 170 & 147 \\
\hline Low & Medium & 330 & 22.8 & 167 & 148 \\
\hline Low & Low & 335 & 23.6 & 169 & 144 \\
\hline \multicolumn{6}{|l|}{ P-values } \\
\hline Protein & & 0.034 & 0.005 & $<0.001$ & $<0.001$ \\
\hline Fat & & 0.280 & 0.311 & 0.382 & 0.985 \\
\hline Protein $x$ Fat & & 0.953 & 0.471 & 0.199 & 0.435 \\
\hline
\end{tabular}

At 37 days of age, differences in chemical composition were observed between dietary treatments (Table 8). Dry matter, Ash and Fat content in broilers fed HP diets was significantly lower than in broilers fed LP diets. Content of CP in broilers fed HP diets was significantly higher than in broilers fed LP diets. Dry matter, Ash, CP and Fat content in broilers at 37 days of age was not affected by dietary fat/starch concentration. 
Table 9 Deposition of crude protein (CP) and fat (Fat) in the body in the period 8 to $18 \mathrm{~d}$, 18 to 28 and 28 to $37 \mathrm{~d}$ of age in $\mathrm{g}$ per broiler

\begin{tabular}{|c|c|c|c|c|c|c|c|}
\hline & \multicolumn{2}{|c|}{$8-18$ d of age } & \multicolumn{2}{|c|}{$18-28 \mathrm{~d}$ of age } & \multicolumn{2}{|c|}{$28-37 d$ of age } \\
\hline & & $\mathrm{CP}$ & Fat & CP & Fat & $\mathrm{CP}$ & Fat \\
\hline & & g & g & g & g & g & g) \\
\hline \multicolumn{8}{|l|}{ Protein } \\
\hline High & & $86^{a}$ & $68^{b}$ & $132^{a}$ & 107 & 145 & 11 \\
\hline Low & & $82^{b}$ & $74^{a}$ & $118^{\mathrm{b}}$ & 107 & 148 & $131^{a}$ \\
\hline \multicolumn{8}{|l|}{ Fat } \\
\hline High & & $81^{b}$ & $63^{b}$ & $117^{c}$ & $101^{\mathrm{b}}$ & $138^{b}$ & 118 \\
\hline Medium & & $86^{a}$ & $74^{a}$ & $125^{b}$ & $106^{b}$ & $146^{\mathrm{ab}}$ & 122 \\
\hline Low & & $86^{a}$ & $75^{a}$ & $132^{a}$ & $115^{a}$ & $156^{a}$ & 129 \\
\hline Protein & Fat & & & & & & \\
\hline High & High & $82^{b}$ & 61 & 124 & 102 & 137 & 111 \\
\hline High & Medium & $88^{a}$ & 70 & 132 & 103 & 148 & 11 \\
\hline High & Low & $90^{a}$ & 74 & 139 & 117 & 151 & 120 \\
\hline Low & High & $80^{b}$ & 65 & 111 & 100 & 138 & 126 \\
\hline Low & Medium & $83^{b}$ & 77 & 119 & 108 & 145 & 129 \\
\hline Low & Low & $81^{b}$ & 75 & 125 & 114 & 160 & 138 \\
\hline
\end{tabular}

$\begin{array}{lrrrrrr}\text { P-values } & & & & & & \\ \text { Protein } & <\mathbf{0 . 0 0 1} & \mathbf{0 . 0 0 4} & <\mathbf{0 . 0 0 1} & 0.927 & 0.609 & \mathbf{0 . 0 3 8} \\ \text { Fat } & \mathbf{0 . 0 0 2} & <\mathbf{0 . 0 0 1} & <\mathbf{0 . 0 0 1} & \mathbf{0 . 0 0 7} & \mathbf{0 . 0 1 3} & 0.505 \\ \text { Protein x Fat } & \mathbf{0 . 0 2 8} & 0.268 & 0.964 & 0.588 & 0.547 & 0.980\end{array}$

Deposition of CP in broilers fed HP diets was significantly higher than in broilers fed LP diets up to 28 days of age (Table 9). In the period from 8 to 18 and 28 to 37 days of age deposition of Fat in broilers fed HP diets was significantly lower than in broilers fed LP diets. Deposition of CP increased in broilers fed diets containing more starch and deposition of Fat increased significantly until 28 days of age in broilers fed diets containing more starch. 


\subsection{Nutrient digestion}

Nutrient digestibility coefficients are presented in Table 10.

Table 10 Digestibility coefficients of nutrients at 37 days of age

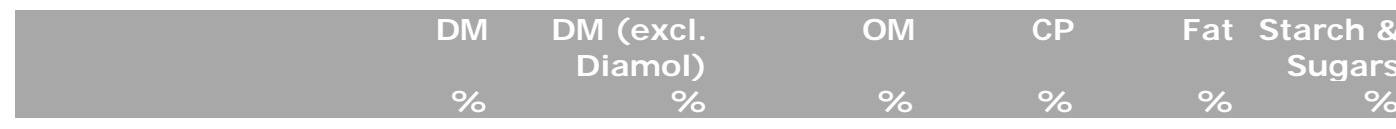

\section{Protein}

High

Low

Fat

High

Medium

Low

\section{Protein}

High

High

High

Low

Low

Low

\section{P-values}

Protein

Fat

Protein $x$ Fat

\section{4 \\ 66}

$52^{c}$
$67^{b}$
$75^{a}$

Fat
High
Medium
Low
High
Medium
Low

75

50
66
75
54
68
75

50

66

75

68

75
0.285

$<0.001$

0.537

69

69
70

$59^{b}$

$73^{a}$

$77^{a}$

\section{8}

73

76

59

73

77

0.818
$<\mathbf{0 . 0 0 1}$
0.979

\section{3}

75

69

74

84

87

97

97

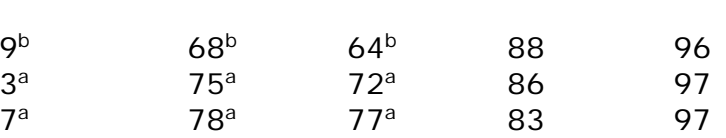

Nutrient digestibility was determined at 37 days of age by collecting excreta from the colon of broilers. Dietary protein did not affect nutrient digestibility (Table 10). Dietary fat however did have an effect on the digestibility of DM, OM and CP. Dry matter, OM and CP digestibility in LF diets was higher than in HF diets. As Diamol was included as an inert filler in the experimental diets, DM digestibility was also calculated without Diamol. Also by excluding Diamol the DM digestibility in LF diets was higher than in HF diets. Fat and Starch+sugars digestibility was not affected by dietary treatment. 


\subsection{Litter quality and foot pad quality}

Quality of litter and foot pad quality are presented in Table 11.

Table 11 Litter quality and foot pad quality

\begin{tabular}{|c|c|c|c|c|c|}
\hline & & $\begin{array}{l}\text { Mean } \\
\text { litter } \\
\text { quality }\end{array}$ & $\begin{array}{r}\text { Foot } \\
\text { pad } \\
\text { lesions } \\
18 \mathrm{~d}\end{array}$ & $\begin{array}{r}\text { Foot } \\
\text { pad } \\
\text { lesions } \\
28 \mathrm{~d}\end{array}$ & $\begin{array}{r}\text { Foot } \\
\text { pad } \\
\text { lesions } \\
37 \mathrm{~d}\end{array}$ \\
\hline \multicolumn{6}{|l|}{ Protein } \\
\hline High & & 1.1 & $0.01^{b}$ & $0.00^{\mathrm{b}}$ & 0.01 \\
\hline Low & & 1.1 & $0.08^{a}$ & $0.08^{a}$ & 0.01 \\
\hline \multicolumn{6}{|l|}{ Fat } \\
\hline High & & $1.2^{\mathrm{a}}$ & $0.03^{\mathrm{ab}}$ & 0.01 & 0.01 \\
\hline Medium & & $1.1^{\mathrm{ab}}$ & $0.09^{a}$ & 0.07 & 0.01 \\
\hline Low & & $1.0^{\mathrm{b}}$ & $0.01^{b}$ & 0.03 & 0.00 \\
\hline Protein & Fat & & & & \\
\hline High & High & 1.2 & 0.02 & 0.00 & 0.02 \\
\hline High & Medium & 1.1 & 0.02 & 0.00 & 0.00 \\
\hline High & Low & 1.0 & 0.00 & 0.00 & 0.00 \\
\hline Low & High & 1.2 & 0.04 & 0.02 & 0.00 \\
\hline Low & Medium & 1.1 & 0.17 & 0.15 & 0.02 \\
\hline Low & Low & 1.0 & 0.02 & 0.06 & 0.00 \\
\hline \multicolumn{6}{|l|}{ P-values } \\
\hline Protein & & 0835 & 0.039 & 0.012 & 1.000 \\
\hline Fat & & 0.044 & 0.053 & 0.165 & 0.624 \\
\hline Protein $\times$ Fat & & 0.909 & 0.099 & 0.165 & 0.255 \\
\hline
\end{tabular}

In general it can be concluded that the litter quality in this experiment was high at all ages (dry and friable litter) and scores for foot pad lesions were very low (good foot pad health). Mean litter quality was not affected by dietary CP concentration (Table 11). Mean litter quality in pens of broilers fed LF diets was higher (dryer and more friable) than in pens of broilers fed HF diets. Dirtiness of feathers was not affected by dietary treatment. Data of dirtiness of feathers were not shown in Table 11 because the score for dirtiness of feathers was 1.0 for all treatment groups. The score 1.0 means that the feathers were clean. Foot pad quality was affected by dietary CP concentration at 18 and 28 days of age. Foot pad quality of broilers fed HP diets was higher (less lesions) than foot pad quality of broilers fed LP diets at both ages. Dietary CP concentration did not affect foot pad quality at 37 days of age. Foot pad quality was affected by dietary fat/starch concentration at 18 days of age. Foot pad quality of broilers fed LF diets was higher (less lesions) than foot pad quality of broilers fed MF diets. Foot pad quality of broilers fed HF diets was intermediate. In general, foot pad quality was improved as birds grew older.

\subsection{Sieve analyses experimental diets}

Results of sieve analyses of grower and finisher diets are presented in Figure 1 and 2, respectively. The sieve analyses are conducted in diet samples after the crumbling process. Diets with medium fat (MF) were not subjected to sieve analyses as these diets are the result of mixing LF and HF diets. 


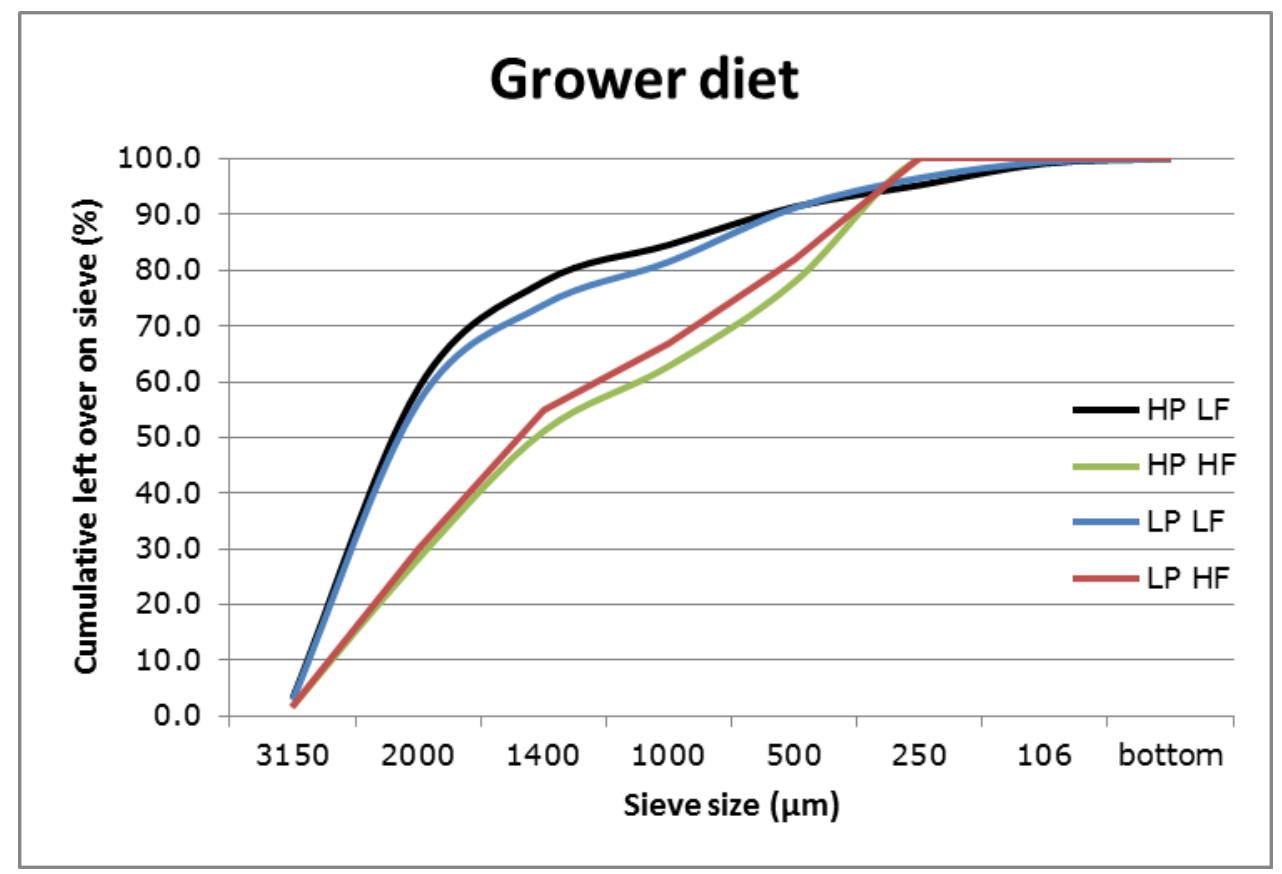

Figure 1. Results of wet sieve analyses experimental grower diets

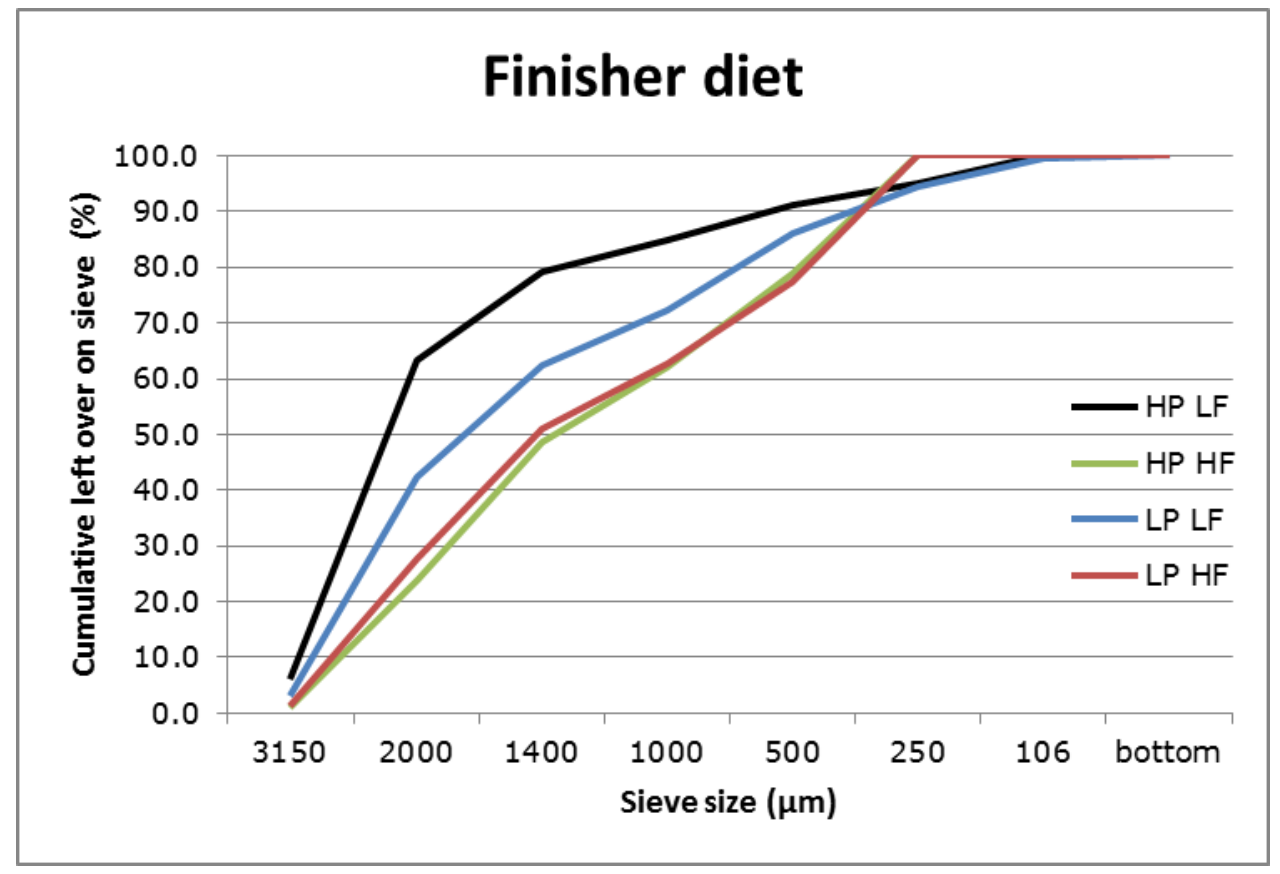

Figure 2. Results of wet sieve analyses experimental finisher diets

From Figure 1 and 2 it can be concluded that the crumbs in LF diets contain more coarse particles than the crumbs in HF diets most probably due to the higher inclusion level of corn in the LF diets. 


\section{Conclusions}

- Protein level and dietary energy source in iso-energetic diets, balanced for most limiting essential amino acids, affect growth performance and body composition of broilers.

- Lowering dietary crude protein concentration with $30 \mathrm{~g} / \mathrm{kg}$ in the grower and finisher period, despite supplementation of free amino acids up to concentrations that meet faecal digestible amino acid requirements $10 \%$ higher than CVB (2012) recommendations, adversely affected growth performance of broilers.

- Partly substitution of fat by starch and sugars as dietary energy source improved growth performance and increased breast meat yield.

- Low protein diets and low fat diets (higher in starch + sugars) resulted in a higher body fat deposition in birds while digestion of fat was not affected by dietary treatment. The observed effects are related to differences in the post-absorptive utilization of amino acids, starch + sugar and fatty acids and retention in the body.

- Overall, litter quality and foot pad quality was high. Dietary crude protein concentration did not affect mean litter quality but foot pad quality in broilers fed high protein diets was higher (less lesions) than in broilers fed low protein diets. Low fat diets (higher in starch + sugars) resulted in a higher litter quality. Foot pad quality of broilers fed low fat diets was higher at 18 days of age. When birds grew older foot pad quality was not affected anymore by dietary fat/starch concentration. 


\section{$5 \quad$ References}

Bennet, W.M., Connacher, A.A., Scrimgeour, C.M., Jung, R.T., Rennie, M.J. 1990. Euglycemic hyperinsulinemia augments amino acid uptake by human leg tissues during hyperaminoacidemia. American Journal of Physiology - Endocrinology and Metabolism 259:E185-E194.

Biolo, G., Declan Fleming, R.Y., Wolfe, R.R. 1995. Physiologic hyperinsulinemia stimulates protein synthesis and enhances transport of selected amino acids in human skeletal muscle. The Journal of Clinical Investigatio 95:811-819.

Buyse, J., Decuypere, E., Berghman, L., Kühn, E.R. Van De Sande, F. 1992. Effect of dietary protein content on episodic growth hormone secretion and on heat production of male broiler chickens. British Poultry Science 33:1101-1109.

Buyse, J., E. Decuypere, V. M. Darras, L. M. Vleurick, E. R. Kuhn, and J. D. Veldhuis. 2000. Food deprivation and feeding of broiler chickens is associated with rapid and interdependent changes in the somatotrophic and thyrotrophic axes. British Poultry Science 41:107-116.

Calbet, J.A.L., D.A. MacLean. 2002. Plasma glucagon and insulin responses depend on the rate of appearance of amino acids after ingestion of different protein solutions in humans. Journal of Nutrition 132:2174-2182.

Camp, L.K., Southern, L.L., Bidner, T.D. 2003. Effect of carbohydrate source on growth performance, carcass traits, and meat quality of growing-finishing pigs. J ournal of Animal Science 81:24882495.

Collin, A., Malheiros, R.D., Moraes, V.M.B., Van As, P., Darras, V.M., Tauois, M., Decuypere, E., Buyse, J. 2003. Effects of dietary macronutrient content on energy metabolism and uncoupling protein mRNA expression in broiler chickens. British Journal of Nutrition 90:261-269.

CVB. 2012. Tabellenboek veevoeding 2012. CVB-reeks nr. 50, Productschap Diervoeder, Den Haag, Augustus 2012.

Eits, R. 2004. Modelling Responses of Broiler Chickens to Dietary Balanced Protein. PhD Thesis. Wageningen University.

Flakoll, P.J., Borel, M.J., Wentzel, L.S., Williams, P.E., Lacy, D.B., Abumrad, N. N. 1994. The role of glucagon in the control of protein and amino acid metabolism in vivo. Metabolism 43: 15091516.

Fulks, R.M., Li, J.B., Goldberg, A.L. 1975. Effects of insulin, glucose, and amino acids on protein turnover in rat diaphragm. The J ournal of Biological Chemistry 250:290-298.

Fuller, M.F., Weekes, T.E.C., Cadenhead, A., Bruce, J.B. 1977. The protein-sparing effect of carbohydrate. 2. The role of insulin. British J ournal of Nutrition 38:489-496.

Houston, B., O'Neill, I.E. 1991. Insulin and growth hormone act synergistically to stimulate insulin-like growth factor-I production by cultured chicken hepatocytes. Journal of Endocrinology 128: 389393.

Jackson, S., Summers, J.D., Leeson, S. 1982. Effect of dietary protein and energy on broiler carcass composition and efficiency of nutrient utilization. Poultry Science 61:2224-2231.

Laurin, D.E., Touchburn, S.P., Chavez, E.R., Chan, C.W. 1985. Effect of dietary fat supplementation on the carcass composition of three genetic lines of broilers. Poultry Science 64:2131-2135.

Macleod, M.G. 1990. Energy and nitrogen intake, expenditure and retention at 20 degrees in growing fowl given diets with a wide range of energy and protein contents. British Journal of Nutrition 64: 625-637.

Macleod, M.G. 1992. Energy and nitrogen intake, expenditure and retention at 32 degrees in growing fowl given diets with a wide range of energy and protein contents. British Journal of Nutrition 67: 195-206.

Malheiros, R.D., Moraes, V.M.B., Collin, A., Janssens, G.P.J., Decuypere, E., Buyse, J. 2003. Dietary macronutrients, endocrine functioning and intermediary metabolism in broiler chickens: Pair wise substitutions between protein, fat and carbohydrate. Nutrition Research 23:567-578.

Mallette, L.E., Exton, J.H., Park, C.R. 1969. Effects of glucagon on amino acid transport and utilization in the perfused rat liver. The J ournal of Biological Chemistry 244:5724-5728. 
Nieto, R., Aguilera, J. F., Fernandez-Figares, I., Prieto, C. 1997. Effect of a low protein diet on the energy metabolism of growing chickens. Archiv für Tierernährung 50:105-119.

Nuttall, F.Q., Mooradian, A.D., Gannon, M.C., Billington, C., Krezowski, P. 1984. Effect of protein ingestion on the glucose and insulin response to a standardized oral glucose load. Diabetes Care 7: 465-470.

Rabinowitz, D., Merimee, T.J., Maffezzoli, R., Burgess, J.A. 1966. Patterns of hormonal release after glucose, protein, and glucose plus protein. Lancet 2:454-456.

Rosebrough, R.W., Mitchell, A.D., McMurtry J.P. 1996. Dietary crude protein changes rapidly alter metabolism and plasma insulin-like growth factor-1 concentrations in broiler chickens. Journal of Nutrition 126:2888-2898.

Scanes, C. G. 2009. Perspectives on the Endocrinology of Poultry Growth and Metabolism. General and Comparative Endocrinology 163:24-32.

Swennen, Q., Janssens, G.P.J., Millet, S., Van Sant, G., Decuypere, E. and Buyse, J. 2005. Effects of substitution between fat and protein on food intake and its regulatory mechanisms in broiler chickens: Endocrine functioning and intermediary metabolism. Poultry Science 84:1051-1057.

Swennen, Q., Decuypere, E., Buyse, J. 2007. Implications of dietary macronutrients for growth and metabolism in broilers chickens. World's Poultry Science Journal 63:541-556.

Tanaka, K., Ohtani, S., Shigeno, K. 1983. Effect of increasing dietary energy on hepatic lipogenesis in growing chicks. 2 . Increasing energy by fat or protein supplementation. Poultry Science 62: 452-458. 


\section{Appendix 1 Feed and nutrient composition of the starter diet}

\begin{tabular}{|c|c|c|c|c|c|}
\hline \multirow[t]{2}{*}{ Feed ingredients } & \multirow{2}{*}{$\begin{array}{r}\text { Concentration } \\
(\mathbf{g} / \mathbf{k g})\end{array}$} & \multirow[t]{2}{*}{ Nutrients } & \multirow{2}{*}{ Units } & \multicolumn{2}{|c|}{ Units/ kg } \\
\hline & & & & Calculated & Analysed \\
\hline Corn & 399.9 & DM & g & 881 & 893 \\
\hline Wheat & 204.5 & ASH & g & 55 & 52 \\
\hline Corn gluten meal (Prairy-Gold) & 1.5 & $\mathrm{CP}$ & g & 220 & 216 \\
\hline Br. Soya bean meal (Hipro FF) & 245.1 & CFATh & g & 71 & 73 \\
\hline Potato protein (Promyl FF) & 38.5 & Cfib & g & 24 & 25 \\
\hline Palm oil & 10.0 & STARCHEwers & g & 360 & 399 \\
\hline Soya oil & 33.9 & SUG & g & 37 & 39 \\
\hline Limestone & 15.4 & $\mathrm{Ca}$ & g & 8.7 & 9.4 \\
\hline Mono-Calcium Phosphate & 11.5 & $\mathrm{P}$ & g & 5.7 & 6.1 \\
\hline Sodium bicarbonate & 3.3 & oP & g & 4.3 & \\
\hline Salt & 1.1 & $\mathrm{Ca}: \mathrm{oP}$ & & 2.4 & \\
\hline DL-Methionine & 2.7 & $\mathrm{Mg}$ & g & 1.4 & \\
\hline L-Lysine $\mathrm{HCl}$ & 2.6 & K & g & 8.1 & 8.2 \\
\hline L-Threonine & 0.7 & $\mathrm{Na}$ & g & 1.4 & 1.5 \\
\hline Clinacox & 5.0 & $\mathrm{Cl}$ & g & 1.8 & 1.9 \\
\hline Glucanase-Xylanase & 2.5 & EB & meq & 221 & \\
\hline Phytase & 0.3 & MEbroiler & kcal & 2925 & \\
\hline \multirow[t]{7}{*}{ Premix broilers ${ }^{1}$} & 5.0 & LYS & g & 13.5 & \\
\hline & & dLYS & g & 12.1 & \\
\hline & & dMET & g & 6.0 & \\
\hline & & dCYS & g & 2.9 & \\
\hline & & $\mathrm{dMET}+\mathrm{CYS}$ & g & 9.0 & \\
\hline & & dTHR & g & 7.9 & \\
\hline & & dTRP & g & 2.2 & \\
\hline
\end{tabular}

${ }^{1}$ Composition of premix: $12,000 \mathrm{IE}$ retinol, 2,400 IE cholecalciferol, $50 \mathrm{mg}$ dl-a-tocopherol, $1.5 \mathrm{mg}$ menadione, $2.0 \mathrm{mg}$ thiamine, $7.5 \mathrm{mg}$ riboflavin, $3.5 \mathrm{mg}$ pyridoxine- $\mathrm{HCl}, 25 \mu \mathrm{g}$ cyanocobalamine, $35 \mathrm{mg}$ niacin, $12 \mathrm{mg} \mathrm{D}$-pantothenic acid, $460 \mathrm{mg}$ choline chloride, $1.0 \mathrm{mg}$ folic acid, $0.2 \mathrm{mg}$ biotin, $86 \mathrm{mg}$ iron, $12 \mathrm{mg}$ copper, $85 \mathrm{mg}$ manganese, $60 \mathrm{mg}$ zinc, $0.8 \mathrm{mg}$ iodine, $0.15 \mathrm{mg}$ selenium, $125 \mathrm{mg}$ anti-oxidant. 


\section{Appendix 2 Growth performance of broilers from 8 to 28 days of age}

\begin{tabular}{|c|c|c|c|c|c|c|}
\hline & & BW 28d & BW gain & FCR & $\begin{array}{r}\text { Feed } \\
\text { intake }\end{array}$ & Mortality \\
\hline & & g & g/d & & g/d & $\%$ \\
\hline \multicolumn{7}{|l|}{ Protein } \\
\hline High & & $1486^{a}$ & $61.1^{a}$ & $1.50^{\mathrm{a}}$ & 91.6 & 1.2 \\
\hline Low & & $1416^{b}$ & $57.7^{\mathrm{b}}$ & $1.59^{b}$ & 91.5 & 1.0 \\
\hline \multicolumn{7}{|l|}{ Fat } \\
\hline High & & $1387^{c}$ & $56.6^{c}$ & $1.59^{a}$ & $89.6^{a}$ & 0.9 \\
\hline Medium & & $1467^{b}$ & $60.1^{\mathrm{b}}$ & $1.57^{a}$ & $94.2^{b}$ & 1.3 \\
\hline Low & & $1498^{a}$ & $61.7^{a}$ & $1.48^{b}$ & $90.9^{a}$ & 1.1 \\
\hline Protein & Fat & & & & & \\
\hline High & High & 1405 & 57.4 & 1.54 & 88.6 & 0.9 \\
\hline High & Medium & 1505 & 61.9 & 1.53 & 94.5 & 1.5 \\
\hline High & Low & 1548 & 64.0 & 1.43 & 91.7 & 1.1 \\
\hline Low & High & 1370 & 55.7 & 1.63 & 90.5 & 0.8 \\
\hline Low & Medium & 1430 & 58.3 & 1.61 & 93.8 & 1.1 \\
\hline Low & Low & 1448 & 59.3 & 1.52 & 90.1 & 1.1 \\
\hline \multicolumn{7}{|l|}{ P-values } \\
\hline Protein & & $<0.001$ & $<0.001$ & $<0.001$ & 0.914 & 0.992 \\
\hline Fat & & $<0.001$ & $<0.001$ & $<0.001$ & $<0.001$ & 0.494 \\
\hline Protein $x$ Fat & & 0.076 & 0.058 & 0.979 & 0.196 & 0.914 \\
\hline
\end{tabular}




\section{Appendix 3 Growth performance of broilers from 29 to 38 days of age}

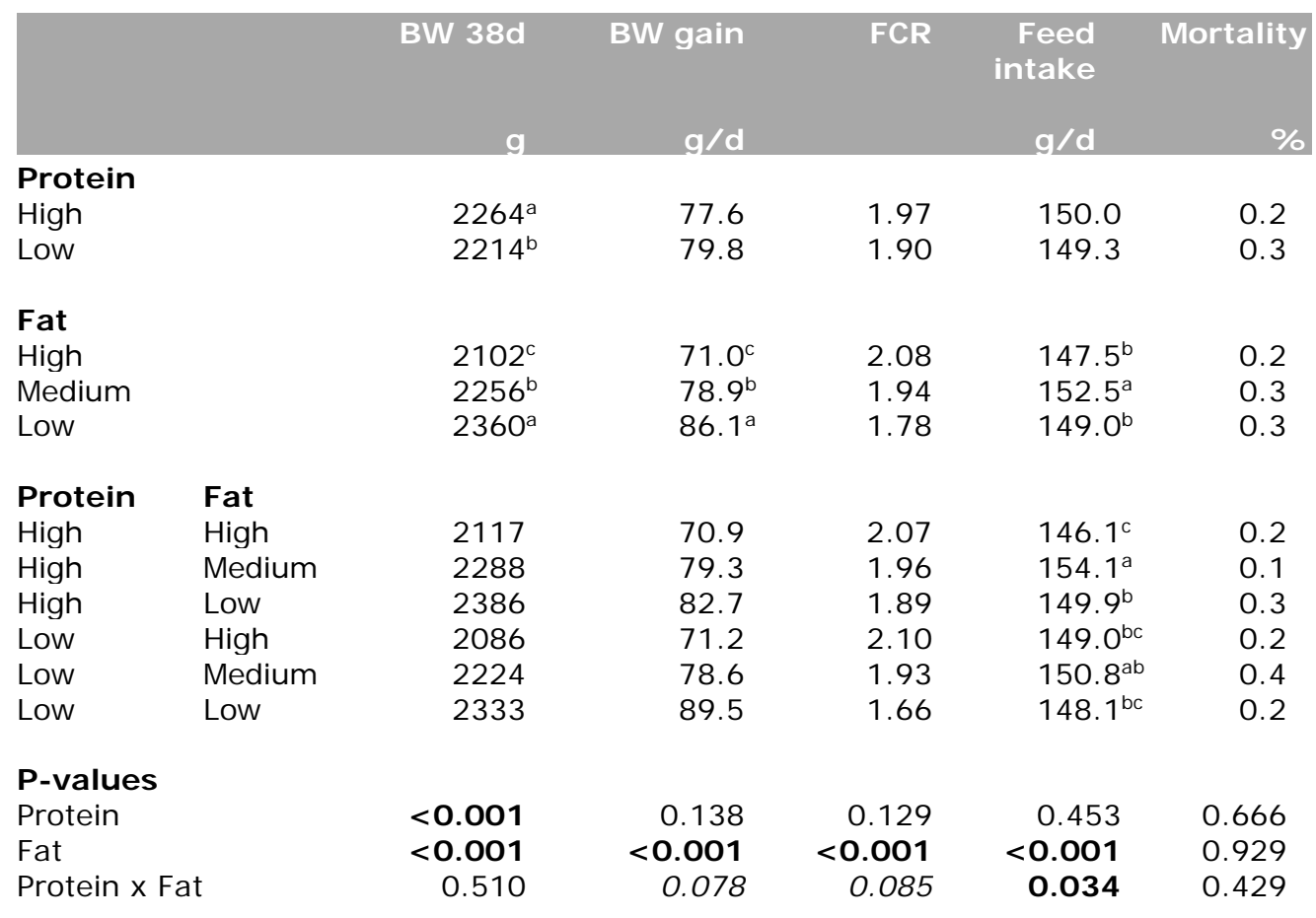





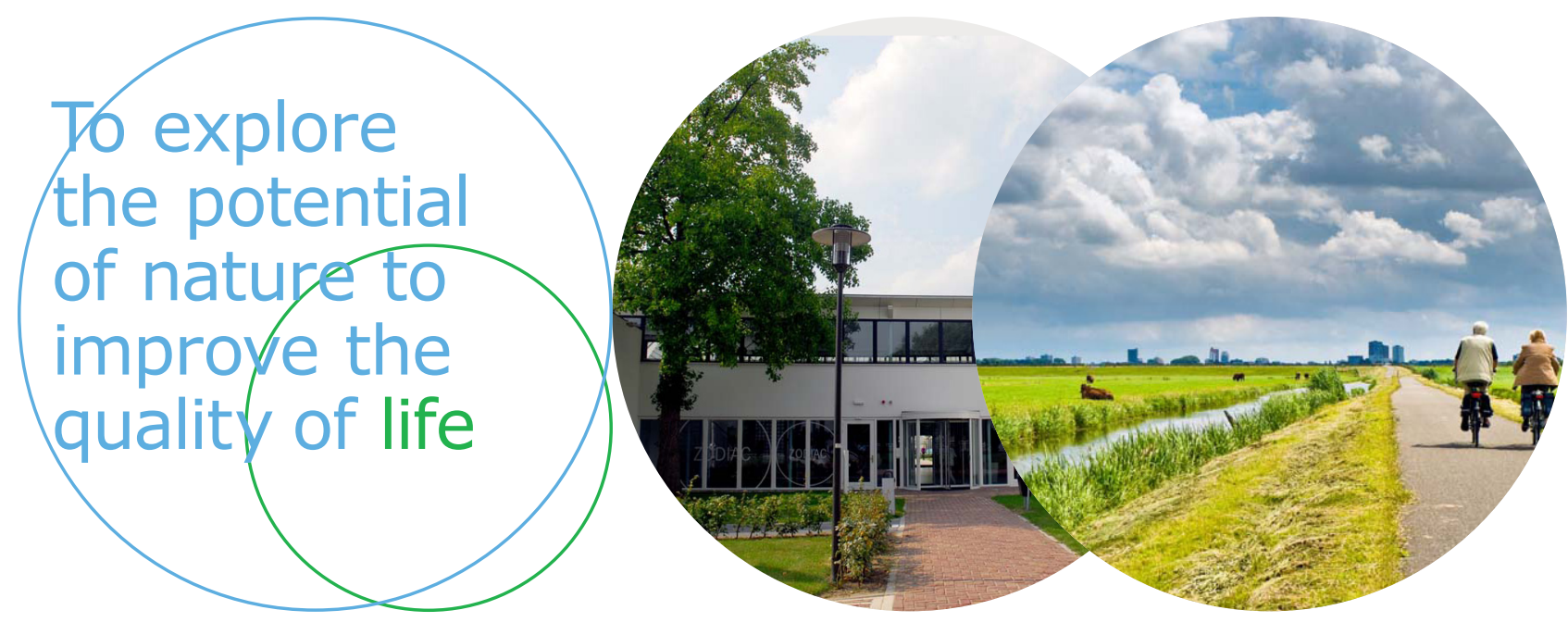

Wageningen Livestock Research P.O. Box 338

6700 AH Wageningen

The Netherlands

T +31 (0)317483953

E info.livestockresearch@wur.nl www.wur.nl/livestock-research

Wageningen Livestock Research creates science based solutions for a sustainable and profitable livestock sector. Together with our clients, we integrate scientific knowledge and practical experience to develop livestock concepts for future generations.

Wageningen Livestock Research is part of Wageningen University \& Research. Together we work on the mission: 'To explore the potential of nature to improve the quality of life'. A staff of 6,500 and 10,000 students from over 100 countries are working worldwide in the domain of healthy food and living environment for governments and the business community-at-large. The strength of Wageningen University \& Research lies in its ability to join the forces of specialised research institutes and the university. It also lies in the combined efforts of the various fields of natural and social sciences. This union of expertise leads to scientific breakthroughs that can quickly be put into practice and be incorporated into education. This is the Wageningen Approach. 